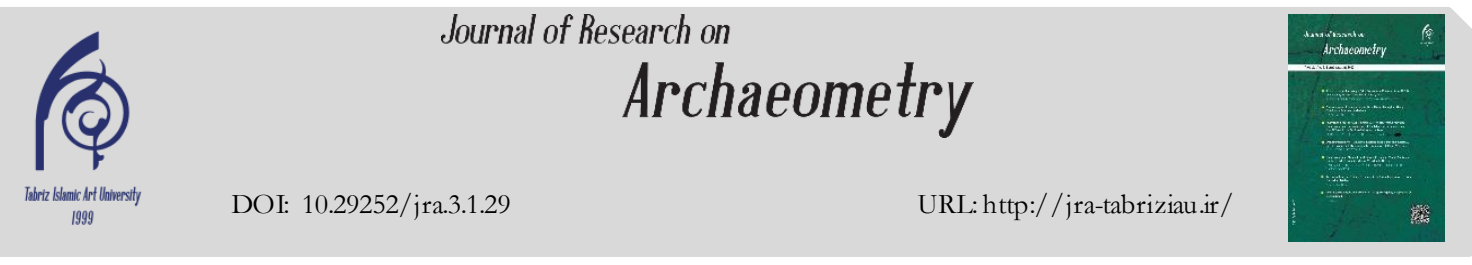

Original Paper

\title{
Identification of Materials and Colorants in Decorative Mosaic Tiles of Musalla Historical Building in Mashhad
}

\author{
Masoud Bater ${ }^{*}$, Maliheh Saberniya ${ }^{2}$, Hossein Ahmadi $^{3}$ \\ ${ }^{1}$ Assistant professor, Department of Conservation and Restoration of Cultural Properties, University of \\ Zabol, Zabol, IRAN \\ ${ }^{2} B A$ in Conservation and Restoration of Cultural Properties, Organization of Libraries, Museums and \\ Document Center of Astane Qudse Razavi, Mashhad, IRAN \\ ${ }^{3}$ Associate professor, Department of Conservation and Restoration of Cultural Properties, Art University of \\ Isfahan, Isfahan, IRAN
}

Received: $31 / 03 / 2017$

Accepted: 15/06/2017

The Mashhad Musalla is one of the largest and most beautiful historic musallas in Iran. Mashhad Musalla has been built during the Safavid Empire, ordered by Suleiman I. Tile's inscription on the Iwan of Musalla gatew ay gives the date of the end of construction, in the year $1087 \mathrm{AH}$. This monument is located at the east of Mashhad. The building has a high porch and two porticoes on both sides. Musalla of Mashhad is constructed of bricks and it was previously using for prayers of the two Eids. The building has been decorated with stucco decoration, tile-working, wall painting and Muqarnas. The building is decorated with stucco decoration, tile-working, painting and Muqarnas. The glazed tile decorations of the Mashhad Musalla include glazed haft-rang and mosaic tiles. During Safavid period, all religious buildings were embellished with tiling decorations. The most prominent decorative element in Mashhad Musalla is tile-working. The tiles in the Mashhad Musalla are predominantly white, black, blue, turquoise, green, yellow and brown. The subject studied in this paper is the creating colorants elements and identification of the chemical composition of the glazed tiles in Mashhad Musalla. Scientific and analytical research was done by Scanning electron microscopy in combination with energy dispersive X-ray microanalysis (SEM-EDX) and Polarized light microscopy (PLM). Scanning electron microscopy (SEM) and energy dispersive X-ray spectroscopy (EDX) were used to determine the elemental compositions of the tile glazes. According to the results obtained, tin (II) oxide together with lead glaze has yielded white color, manganese oxide had been responsible for black color, cobalt (II) together with magnesium oxide and fluorine has yielded blue color, copper oxide was responsible of the turquoise color, lead glaze with the low content of iron oxides has yielded a brown hue, yellow color is attained by lead antimonite and copper oxide together with lead glaze had been responsible for green color. The comparison of the results of the chemical analysis of the Safavid glazed tiles in historic Musalla of Mashhad and results obtained by other scholars who have worked on the identification of the elemental composition of the glaze of Safavid tiles in the other monuments of Iran, indicated that the creating colorant elements were the same, with a little difference, during the seventeenth century and over the Safavid period in Iran. Finally, thin-section analysis under a polarizing microscope was applied to study the petrographic composition on the tile samples. The results of structural study and mineralogical composition of the body mosaic tiles of Mashhad historical Musalla by petrography method showed that the presence of Muscovite,

\footnotetext{
* Corresponding author: masoud.bater@gmail.com
} 
Hornblendes, Biotite, Quartz and Feldspar minerals as the main crystalline phases within the samples. Based on the applied methods, the mineralogical analysis of tile bodies has revealed some considerable results on the composition of this kind of tiles. Apart from minor differences related to the groundmass composition, all the tile bodies examined by thin-section analysis show similar microstructure characteristics and analogous petrographic compositions. On the other hand, the results of the elemental analysis of the glaze of Safavid tiles and considering little difference between chemical composition of the Safavid glazed tiles of the Mashhad historical Musalla and the elemental composition of the glaze of Safavid tiles in the other regions of Iran, it can be deduced that the raw materials used have probably been provided from the local resources.

Keywords: Mosaic tile, Mashhad Musalla, Petrography, SEM-EDX. 


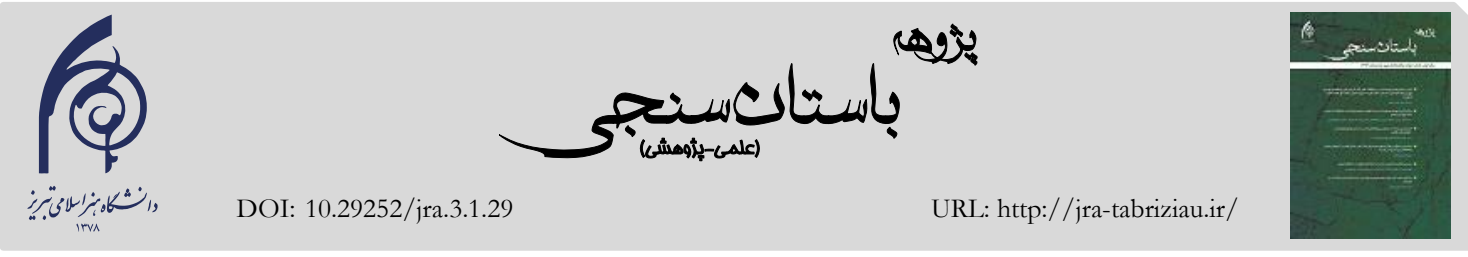

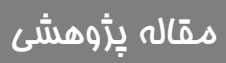

\section{$\bigodot_{\text {CrossMark }}$ معرق بناى تاريخى مصلاى مشهرد

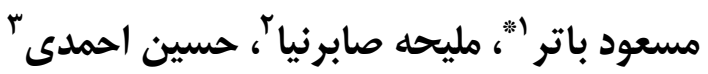

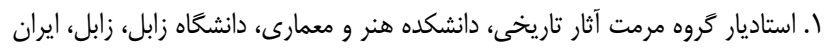

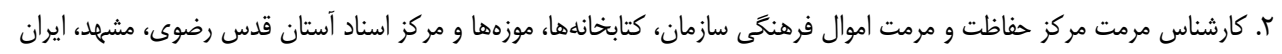

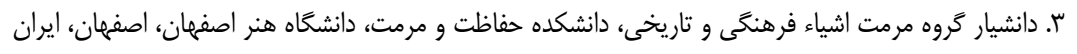

مصلاى مشهد، يكى از بزركترين و زيباترين مصلاهاى تاريخى ايران است. اين مصلا در عصر صفويان و به دستور شاه سـليمان اول

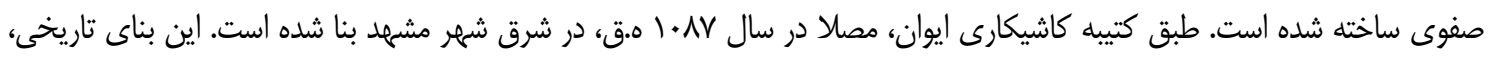

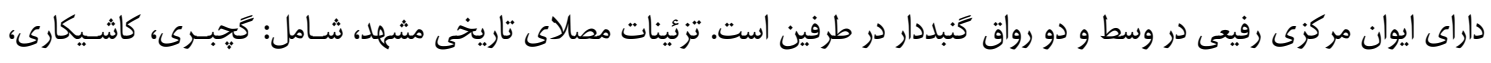

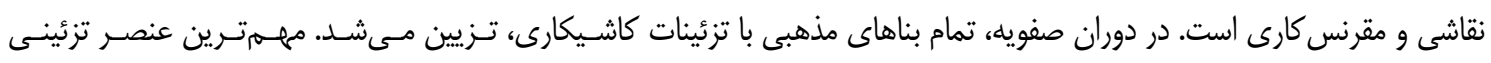

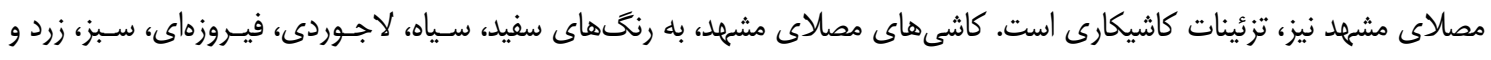

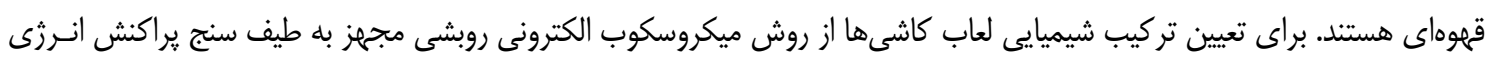

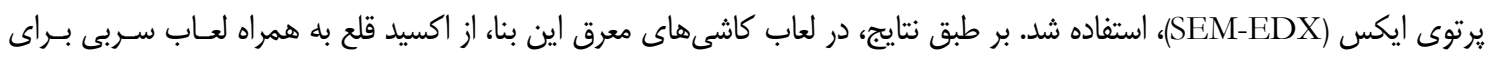

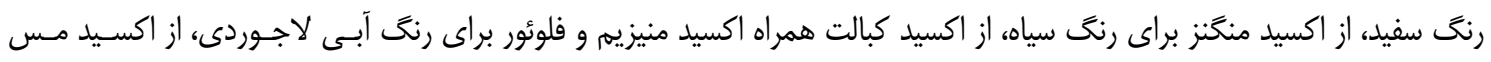

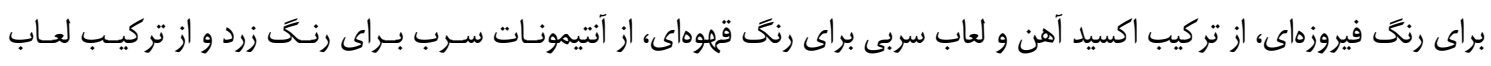

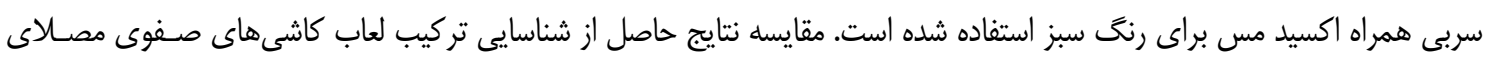

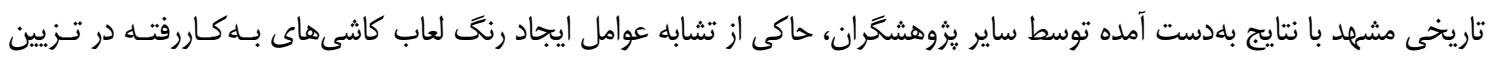

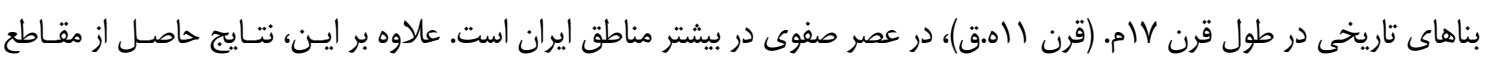

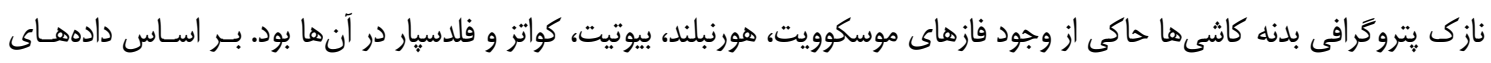

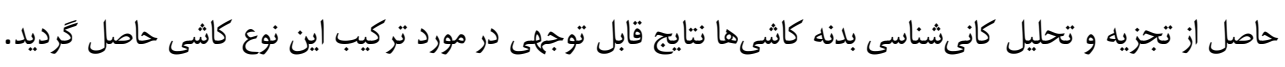

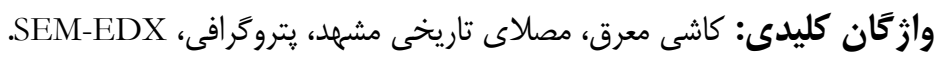

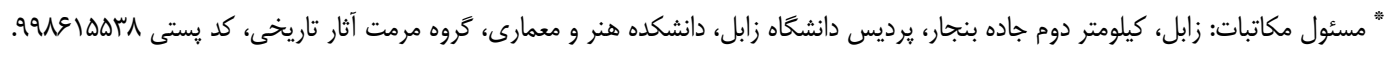

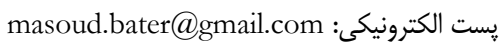

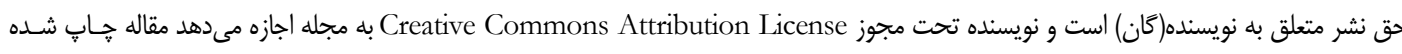
را با ديخران به اشتراك بحذارد منوط بر اينكه حقوق مؤلف اثر حفظ و به به انتشار اوليه مقاله در اين مجله اشاره شود. 


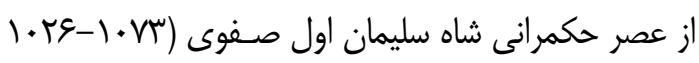

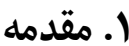
ه.ش) است كه طبق كتيبههاى كاشى معـرق موجـود بـر

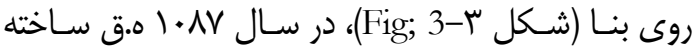
شده است[5-1,3]. طبـق كَفتـه يـوض (Pope) و دى يـز

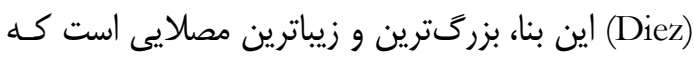

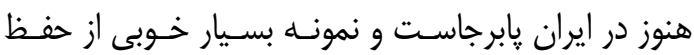
كيفيت بالاى معمارى ايران، حتى در پايـان سـده ل1 1 ه.ق

بناى تاريخى مصلاى مشهر، داراى يلانى مستطيل

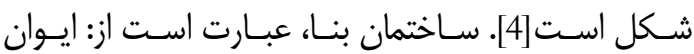

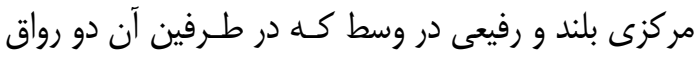
كَنبدار (شكل r-Fig; 2) بنا شده است [1]. در وسط ضلع

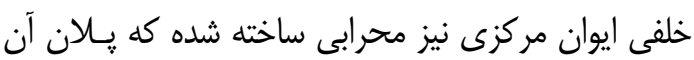

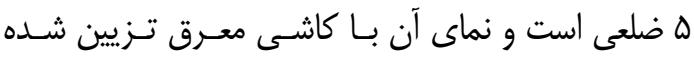

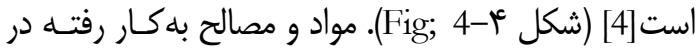
ساخت ايوان مركزى و دو رواق كَنبـدار مجـاور آن، آجــر

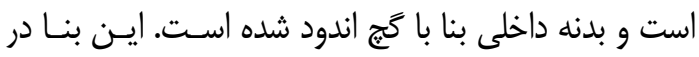
سال •اسا هجرى شمسى به شماره أما در فهرست آثار

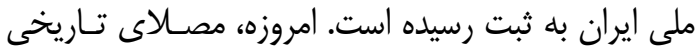
مشهد در اختيار سازمان ميراث فرهنخـى، صـنايعدستى و و

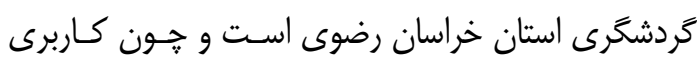

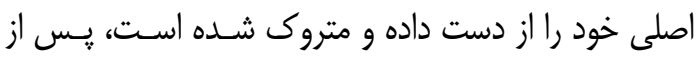
انجام عمليات مرمت آن در طى ساليان كذشـــه، كـاربرى

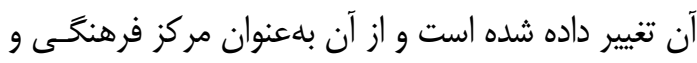

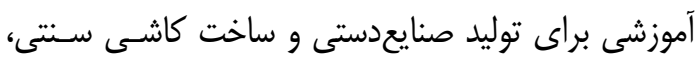

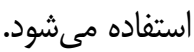

هدف از مطالعه حاضر، شناخت تركيب لعاب و عوامل

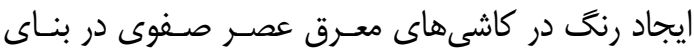

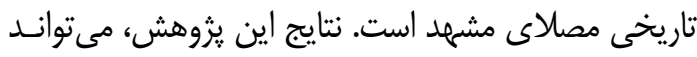

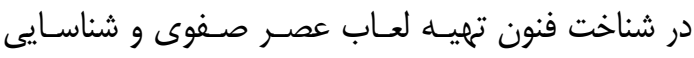
رنخدانههاى بهكاررفته در كاشىهاى رنغارنــ ايسن دوره

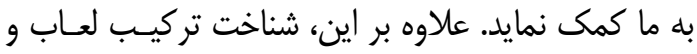

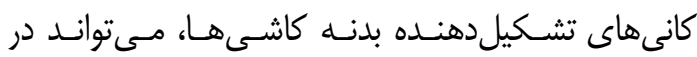
يزوهششهاى مرتبط با بررسى رونـــ فرسـايش و تخريسب لعاب در كاشىهاى معرق، بسيار مفيد باشد. با وجودى كه در معمارى اسلامى، در هر شـهرى مســد

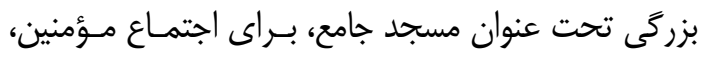

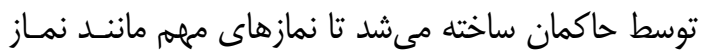

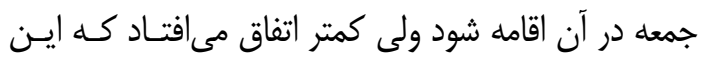

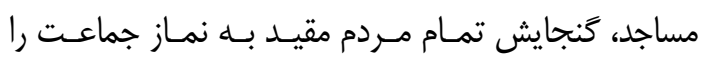

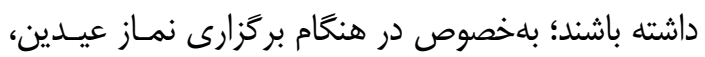

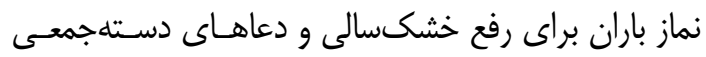

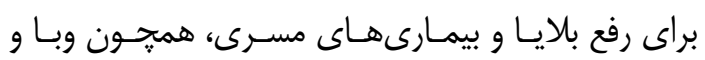

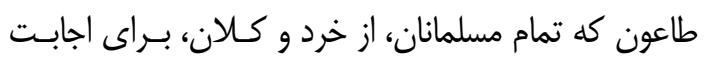

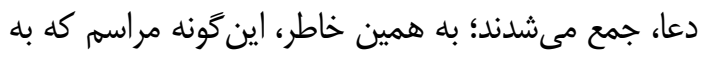

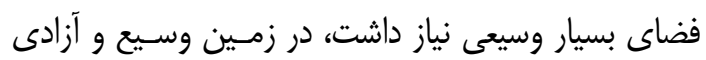

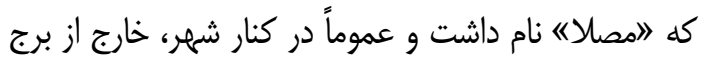

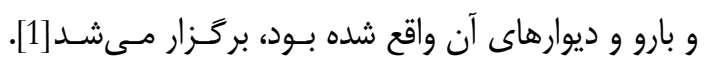

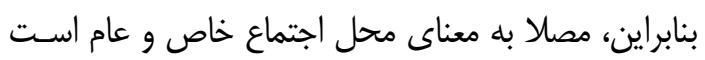
در قطعه زمينى وسيع و آزاد كه قبلا در خارج شهمر آمـاده

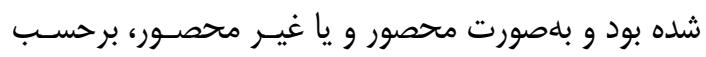

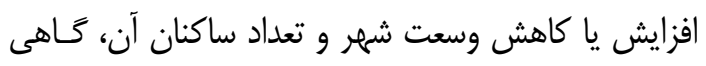

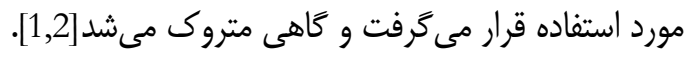

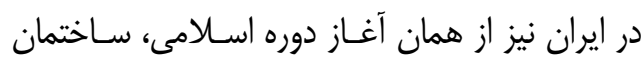

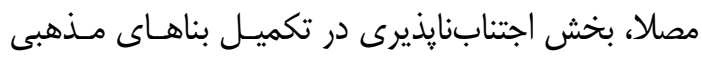

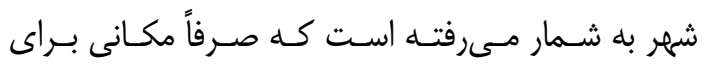

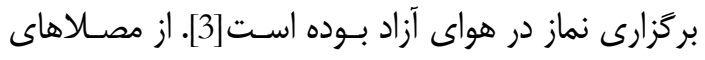

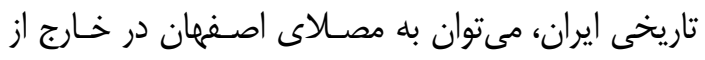

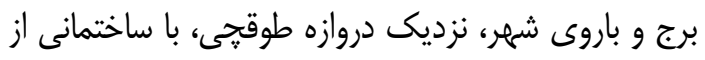

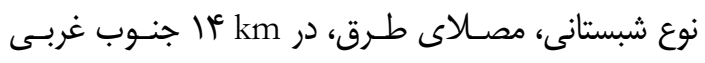

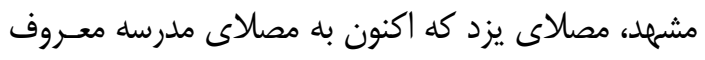

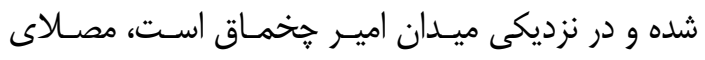

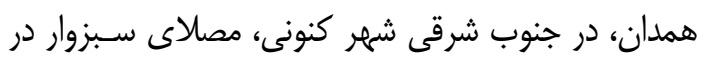

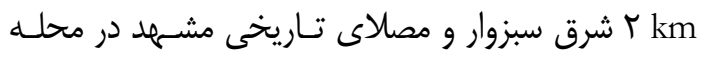
پايين خيابان مشهر اشاره كرد[1,2,4]. مصلاى تاريخى مشهلد، در يايين خيابان مشهد (بلوار

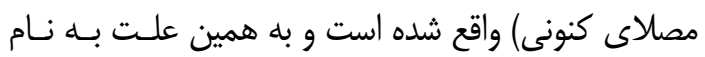
مصلاى بايين خيابان مشهد نيز شناخته مى شــود (اشـكال

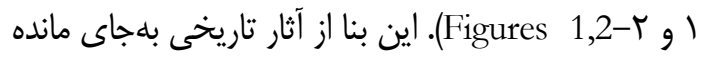




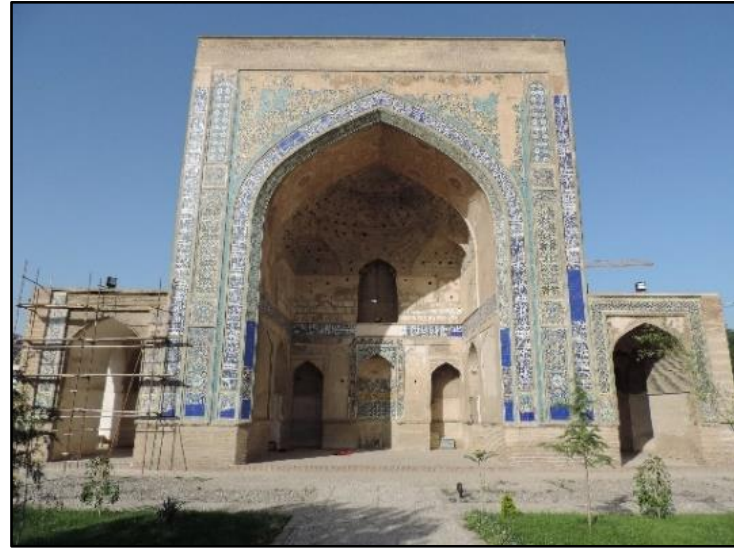

شكل ז: نماى اصلى بناى مصلاى تاريخى مشهد

Fig; 2: The main facade of Mashhad historical Musalla

آن ها مشاهده مىشود.

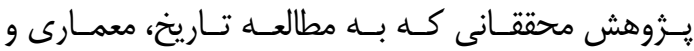

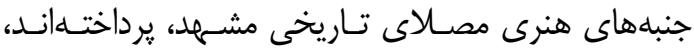

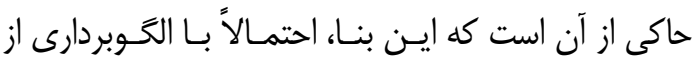

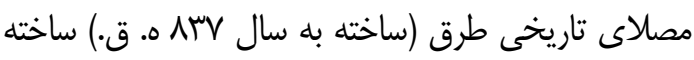

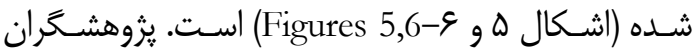
متعددى در آثار خود بر كيفيت برجسته معمارى، مرندسى ساخت و ظرافت و زيبايى فوقالعـاده هنـر كاشـيكارى در مصـلاى تــاريخى مشــهد (شـكل V-V Fig; 7-V)، تأكيــد

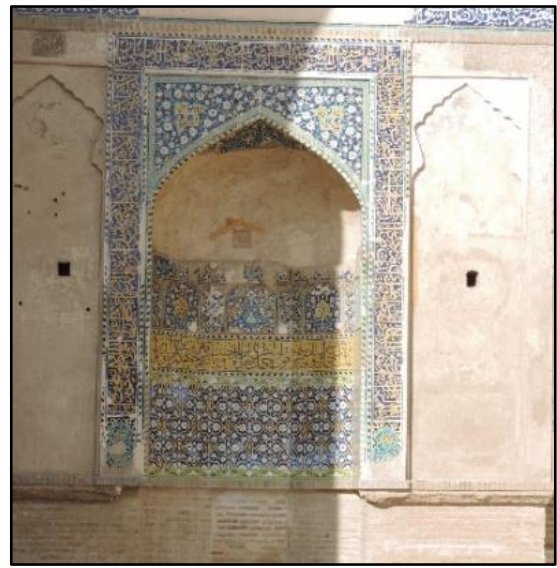

شكل أ: محراب كاشيكارىشده بنا در وسط ايوان مركزى با پالان ينج تصلعى

Fig; 4: Mihrab tile in the middle of the central porch with a pentagon plan

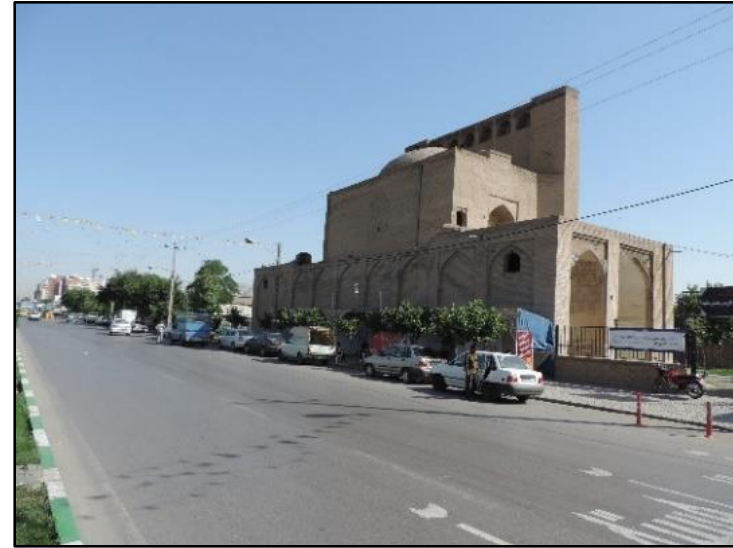

شكل (: موقعيت قرارَيرى مصلاى تاريخى مشهر در حاشيه بلوار

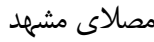

Fig; 1: Location of Mashhad historical Musalla on Musalla Blvd.Mashhad

\section{r. بيشينه تحقيق}

يزوهشهايى كه درباره مصلاى تـاريخى مشـهد انجـام شده، بسيار اندى و محدود است. از سوى ديگر، اين بنـا در بيشتر اين تحقيقها نيز، تنها از منظـر تـاريخى و بـر اساس مشاهدات ميــانى و مطالعـه كتابخانـهاى، مـورد بررسى و مطالعه قرار گرفته است. بدين ترتيب در آثار و نوشتههاى بلهجاى مانده در اين زمينه بلندرت نشـانى از

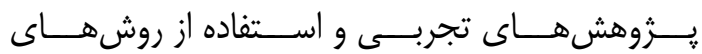
آزمايشگاهى، براى شناخت مواد و مصالح به كار رفتـه در

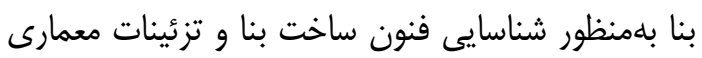

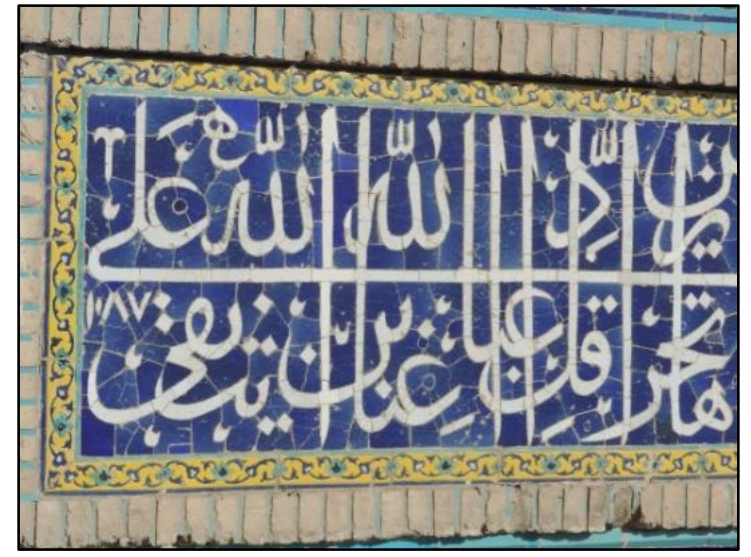

شكل "ا: درج تاريخ ساخت بنا بر روى كتيبه كاشيكارى نماى ايوان اصلى

Fig; 3: Insert date of the construction on the tile inscription of the main facade of the porch 


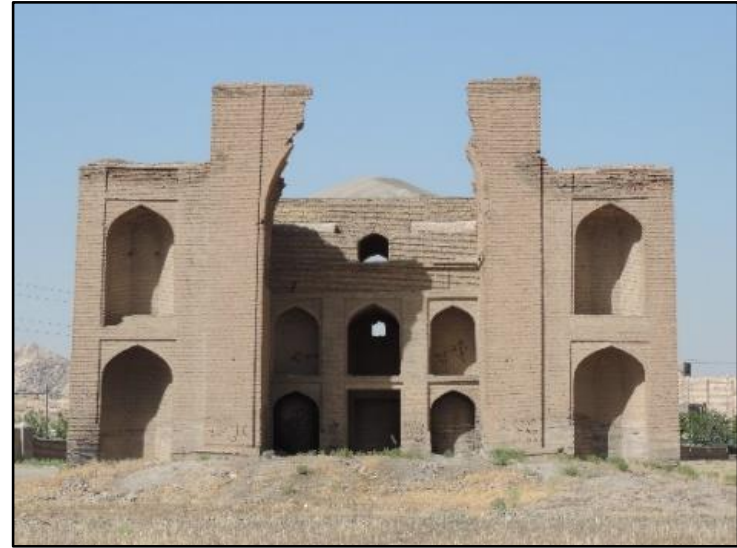

شكل \&: نماى ايوان اصلى مصلاى تاريخى طرق

Fig; 6: The main porch facade of Toroq historical Musalla

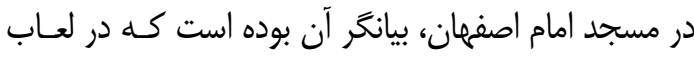

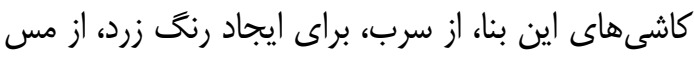

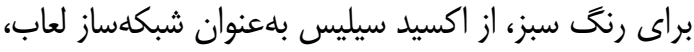

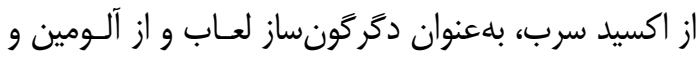
اكسيد قلع نيز بلعنوان كمك شبكه سـاز لعـاب، اسـتفاده شده است[8]. شناسايى تركيـب شـيميايى لعـاب صـفوى كتيبه خط ثلث كاشى در ايوان جنوبى حرم امام على (ع) در نجف اشرف به روش ميكروسكوٍ الكترونسى روبشى ديى

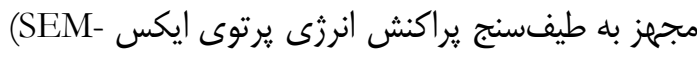

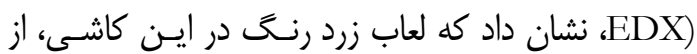
نوع سربى است و در تركيب ايـن لعـاب، اثـرى از اكسـيد

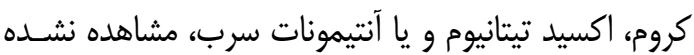

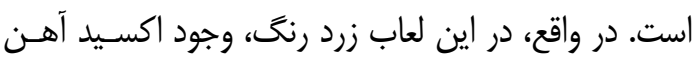

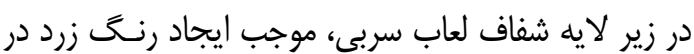

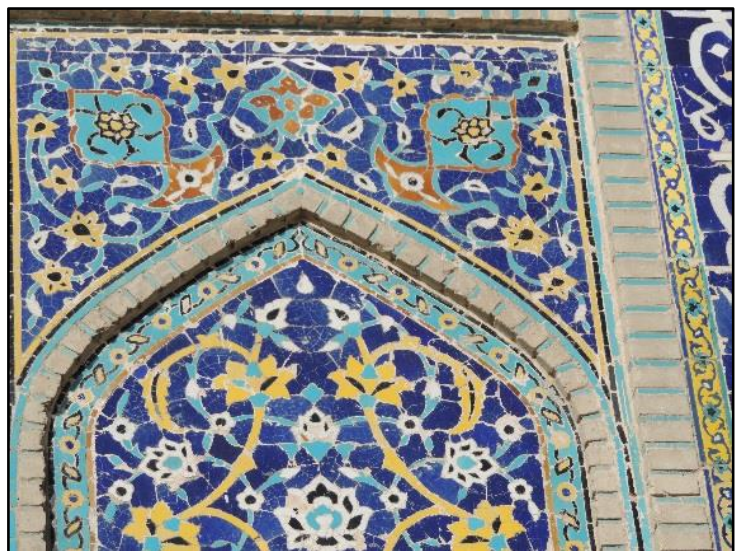

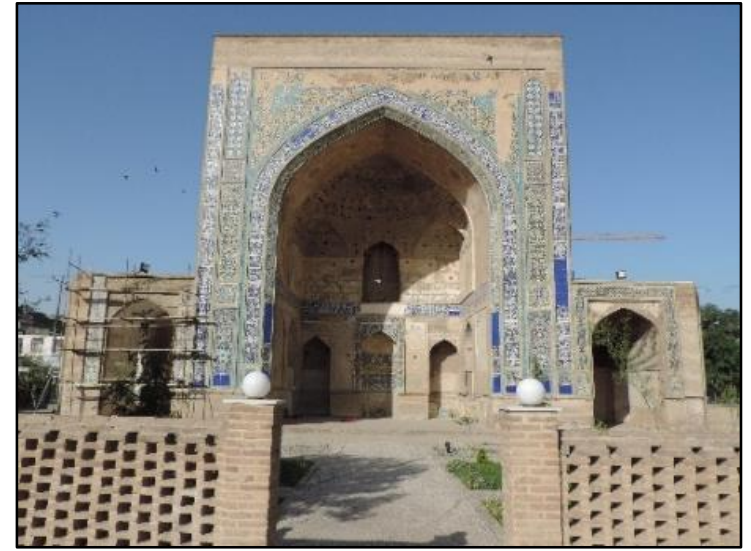

شكل ه: نماى ايوان اصلى مصلاى تاريخى مشهد

Fig; 5: The main porch facade of Mashhad historical Musalla

بررسى تركيب لعـاب كاشـىهـاى برخى از بناهـاى

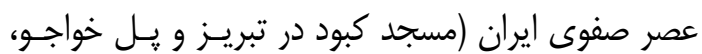
مسجد امام و مدرسه جهارباغ در اصفهان) بـه روش نشـر

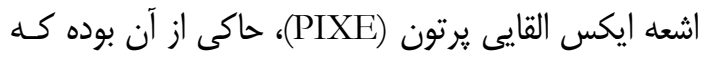

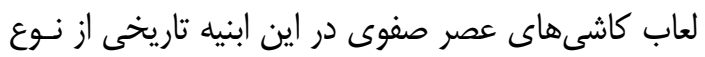

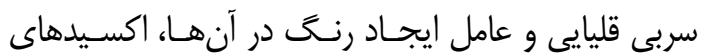

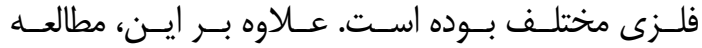
آزمايشگاهى انجامشــه، نشـان داده اسـت كـهـ در لعـاب

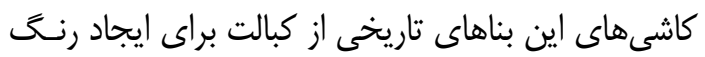

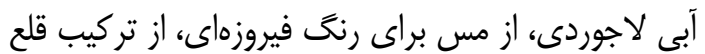
و سرب براى رنخ زرد و از منگنز براى رنخ سياه استفاده شده است[7]. بررسى لعاب كاشىهاى هفترنغ صففوى

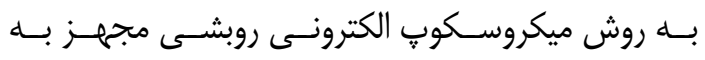
طيفسنج يراكنش انرزى يرتوى ايكس (SEM-EDX)،

شكل V: نمايى از كاشىهاى بسيار زيباى معرق بلكاررفته در مصلاى تاريخى مشهد

Fig; 7: A view of the absolutely beautiful of mosaic tiles used in Mashhad historical Musalla 
اصلىترين، شيوه تـزيين ابنيـه مـذهبى در عصـر صـفوى

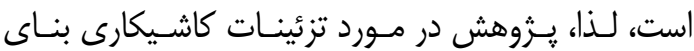
تاريخى مصلاى مشهد بلعنوان مهمترين نمونه بـهــاى

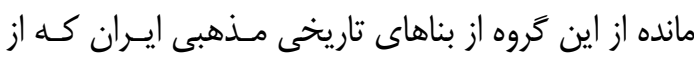
آثار شاخص عصر صفوى است، به روش تجربى با استفاده از بررسىهاى آزمايشكاهى از اهميت و ارزش خاصى بـ بـهـ لحاظ مطالعه موادشناسى و باستانسنجى برخوردار است.

\section{آ. مواد و روشها}

اين يزوهش كاربردى با اسـتفاده از روشهـاى يزوهشى تجربى - تحليلى انجام شده است. براى جمع آورى دادههـا از روشهاى مختلف، شامل: مطالعه كتابخانـایى، مطالعـه ميدانى و بررسى آزمايشخاهى، استفاده شده است.

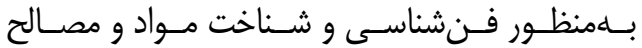
بهكاررفته و شـيوه سـاخت لعـاب در تزئينـات كاشـيكارى معرق عصر صفوى در بنـاى مصـلاى مشـهلد و شـناخت

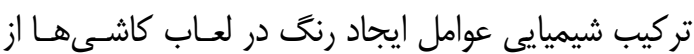
روش تجزيه دسـتخاهى ميكروسـكوٍ الكترونسى روبشـى مجزز به طيفسنج يراكنش انرزى يرتوى ايكس-SEM)

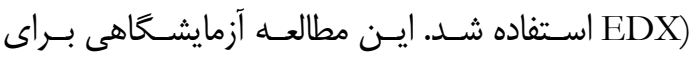
شناخت تركيب عناصر تشكيلدهنده لعاب و عوامل ايجـاد رنخَ در آنها با استفاده از ميكروسـكوٍ الكترونسى مـدل VEGW2 ساخت شركت TESCA جمهـورى جـك در يزوهشكده متالورزى رازى تهران انجام شد. براى مطالعهـ

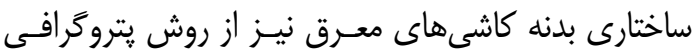

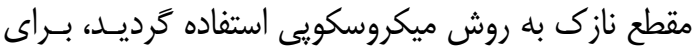
اين منظور از ميكروسـكوٍ پِاريـزان مــل، Olympus،

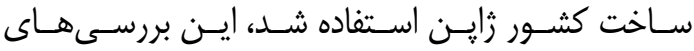

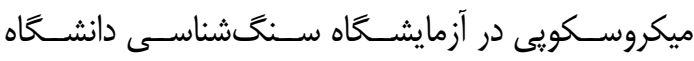
فردوسى مشهر انجام گرديد. در پيايان با تجزيسه و تحليـل

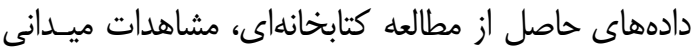
و بررسى آزمايشگاهى، نتايج تحقيق ارائه گرديد.

f أنتايج و بحث در يافتهها f - f ا مشاهدات ظاهرى و نمونلبردارى مطالعاتى كه بلهورت مشاهدات بصرى بر روى تزئينـات بناى تاريخى مصلاى مشهلد انجام شد، حاكى از آن اسـت

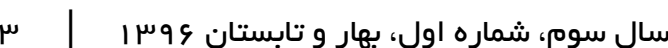

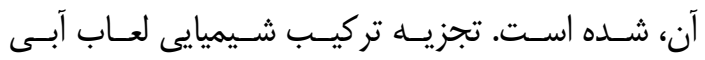
لاجوردى در كتيبه كاشى اين بنا نيز حاكى از وجود اكسيد

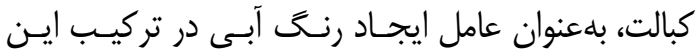
لعاب، بوده است[9]. مطالعه آزمايشخاهى لعاب كاشىهـاى إنى

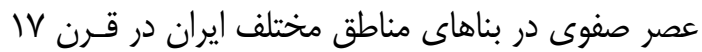
م (قرن II 1 ه.ق)؛ همجون: مسجد جامع عباسى، كليسـاى بيتاللحم و عالىقايوى اصفهان، مسـجد جـامع قـزوين و جشمه عمارت بهشهر و مدرسه عباسقلى خان مشهمهد بــه

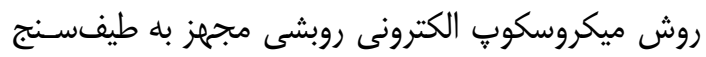

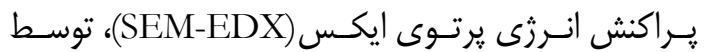
هلاكويى، حاكى از آن بوده است كه در كاشىهاى عصـر

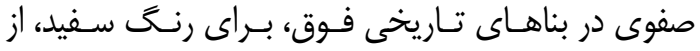

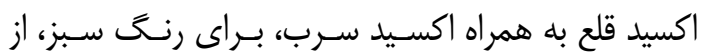

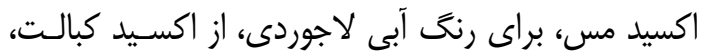
براى رنح زرد از تركيب اكسيد سرب و اكسيد قلع، بـراى رنخ فيروزهاى از اكسيد مس در لعاب سرب قليايى، براى

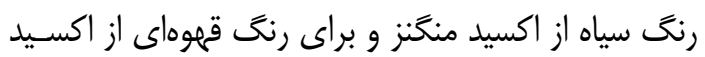

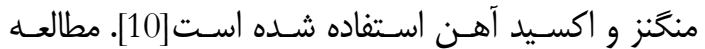
ميشمست و هولاكويى بر روى لعـابهـاى كاشىهــاى صفوى امامزاده اسماعيل قزوين و تجزيه عنصرى تركيب لعاب كاشىها، به روش الكترون ميكرو يروب (EPMA)،

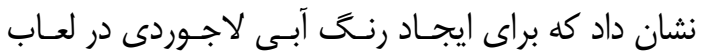

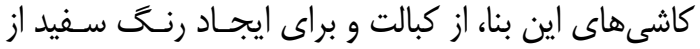
لعاب سرب قليايى با درصد بالايى از قلع و سرب، اسـتفاده

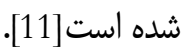
مرور ادبيات و ييشينه تحقيق، حاكى از آن اسـت كـهـ

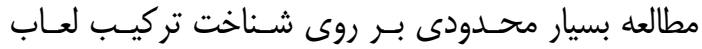
كاشـىهــاى عصـر صـفوى بــهـ روشهــاى تجربـى و آزمايشگاهى انجام شده است و در بيشتر موارد، معمارى و و

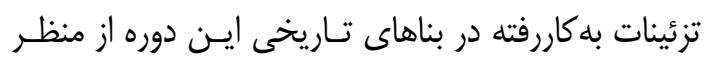
تاريخى، معمارى و هنـرى مـورد مطالعها و بررسى قـرار

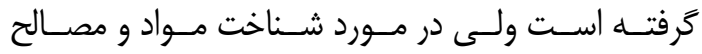
بلهكارفته در ساخت بناهاى عصر صفوى و تزئينات آنها، تاكنون يزوهشهاى اندكى به شيوه تجربسى انجـام شــه است، خاصه آن كه تزئينات كاشيكارى در بناهاى تـاريخى لـاني عصـر صـفوى، بـهويـزهن در بناهـاى مـذهبى ايـن دوران؛

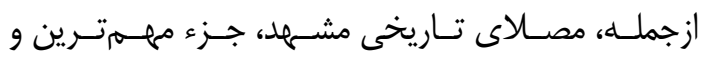


صفوى نبود و از مدتهــا قبـل، از اواخـر دوره ايلخـانى و

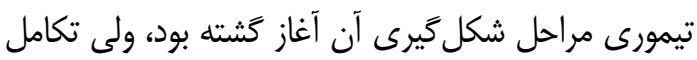

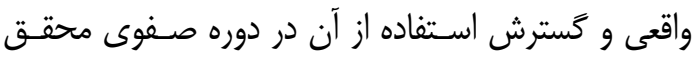
شد[12,13]. علـت اسـتفاده از كاشى معـرق در تزئينـات

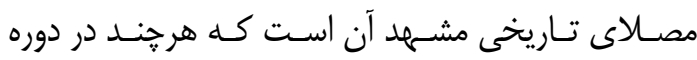
صفوى، روش مرسوم تزئينـات كاشـيكارى در ابنيـه ايـن دمان دوران، كاشى هفترنگ بوده است ولى رواج كاشـيكارى

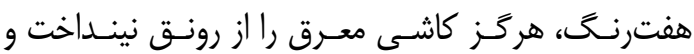

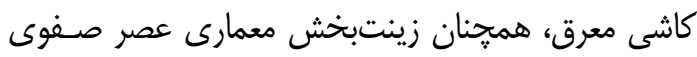

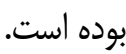
كزارش مرمتهاى انجام شـــه در مصـلاى تـاريخى

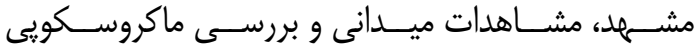

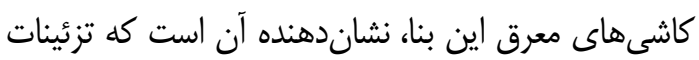
كاشيكارى نماى ايـوان مركـزى، در برخى از منـاطق تـا

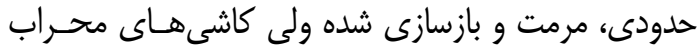

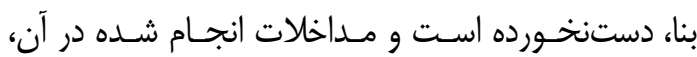

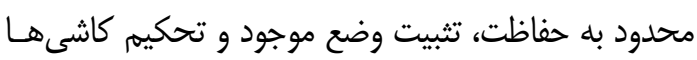

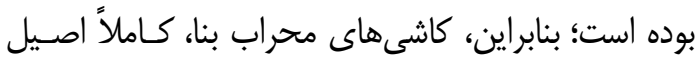

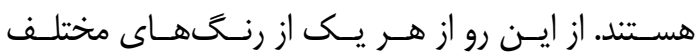

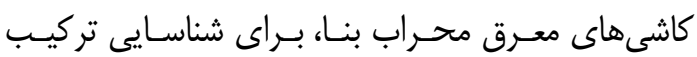

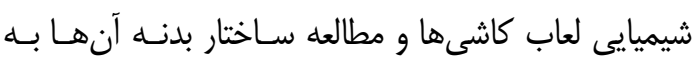

كه مهمترين بخش تزئينات معمارى اين بنـا جـهـ از نظـر كمى و جه كيفى، تزئينات كاشيكارى است كه بـ بـا زيبـايى بسيار، بخش اعظم بدنه اين بنا را زينت داده است. در اين

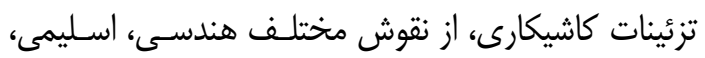

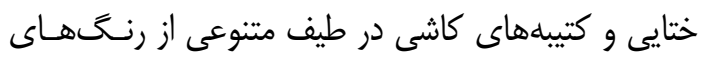

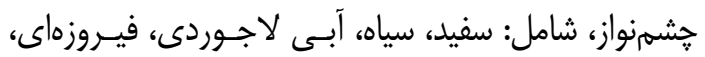

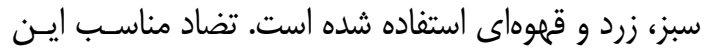

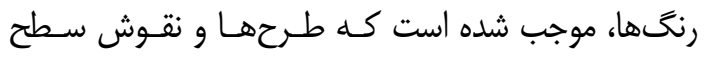

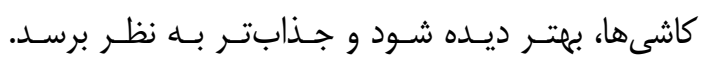

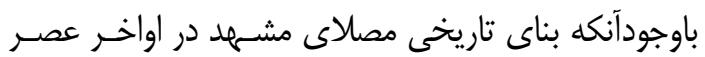
صفويه، در زمان شاه سليمان اول صفوى در سـال 1.1.

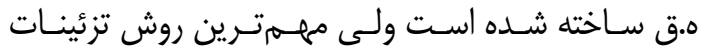

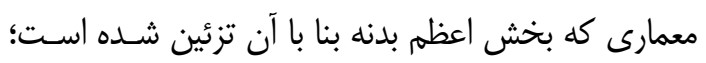

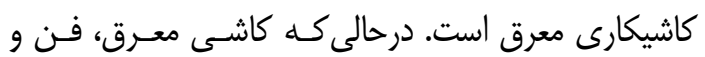
روش برتر و رايج تزئين بنا در عصـر تيمـورى اسـت و در

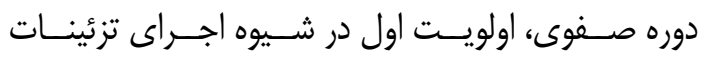

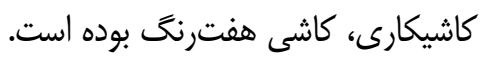

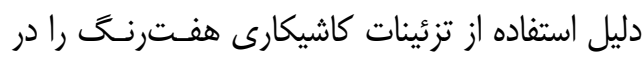

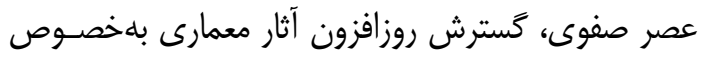

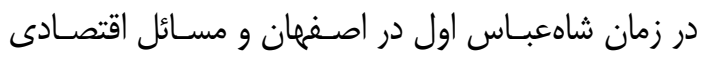

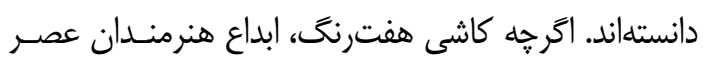

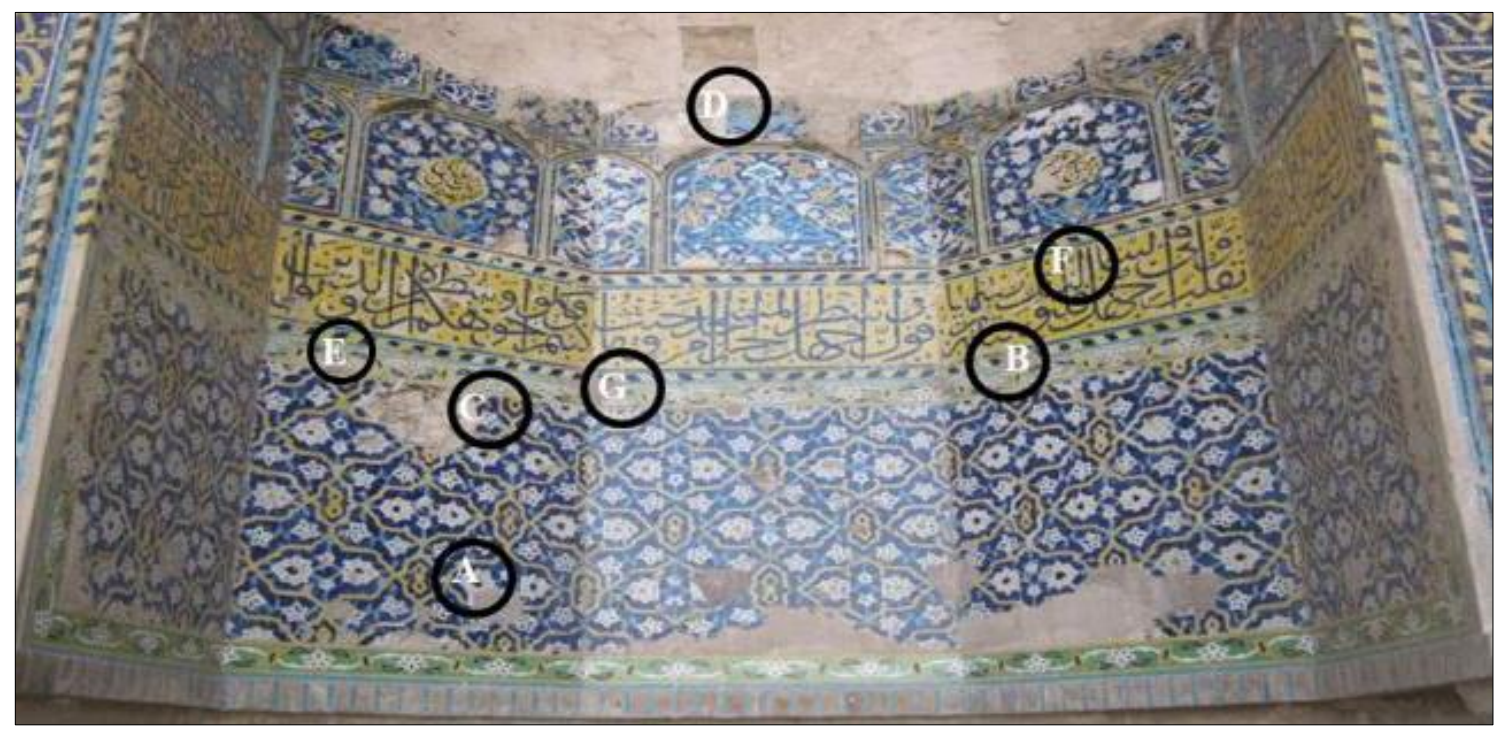

شكل م: محل نمونهبردارى از كاشىهاى معرق اصيل محراب مصلاى تاريخى مشهد كه با دايره سياهرنخ مشخص شده است، A) رنخ سفيد،

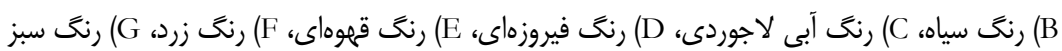

Fig; 8: Sampling location of original mosaic tiles of the mihrab of Mashhad historical Musalla is marked with a black circle, A) White color, B) Black color, C) Blue color, D) Turquoise color, E) Brown color, F) Yellow color, G) Green color 
سفيد رنغ در كاشىهاى معرق اين بنا (شكل 9-9ig; 9-9) و نتايج حاصل از آن (جدول ا-1-1Table)، نشـان داد كـهـ

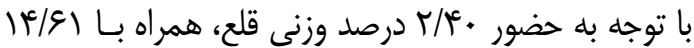
درصد وزنى سرب در اين نمونه لعاب، رنغ سفيد در ايـن

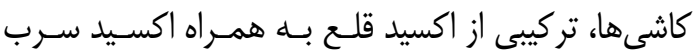

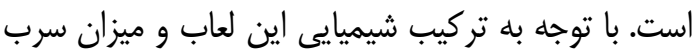

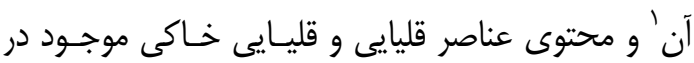

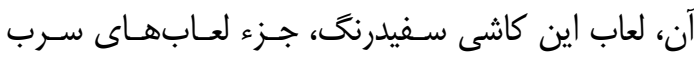
قليايى است[15].

بررسـى طيـف حاصـل از تجزيـهـ عنصـــى لعـاب

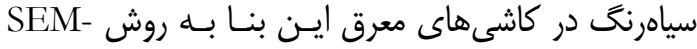

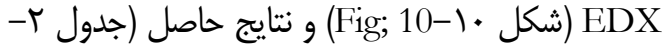

جدول ا: نتايج تجزيه عنصرى نمونه لعاب كاشى سفيدرنگ

Table 1: Elemental analysis results of the white glaze

\begin{tabular}{|c|c|c|}
\hline $\begin{array}{c}\text { درصد اتمى } \\
\text { Atomic percent } \\
\text { A\% }\end{array}$ & $\begin{array}{c}\text { درصد وزنى } \\
\text { weight percent } \\
\text { w\% }\end{array}$ & نام عنصر \\
\hline 5.06 & 3.51 & $\mathrm{Na}$ \\
\hline 10.03 & 7.35 & $\mathrm{Mg}$ \\
\hline 10.84 & 8.82 & $\mathrm{Al}$ \\
\hline 59.42 & 5.37 & $\mathrm{Si}$ \\
\hline 4.49 & 4.35 & $\mathrm{~S}$ \\
\hline 1.37 & 1.59 & $\mathrm{~K}$ \\
\hline 5.72 & 6.95 & $\mathrm{Ca}$ \\
\hline 0.66 & 2.40 & Sn \\
\hline 2.32 & 14.61 & $\mathrm{~Pb}$ \\
\hline
\end{tabular}

مقدار بسيار اندكى، نمونهبردارى شد تا نمونـهـهـاى مـورد

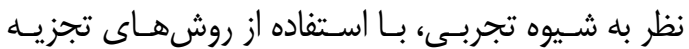

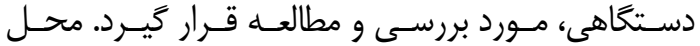

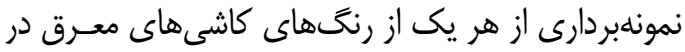
شكل 1، مشخص شده است.

F-F SEM-EDX

وضعيت ساختار لعاب در آثار سفالى لعابدار ازجمله كاشىها

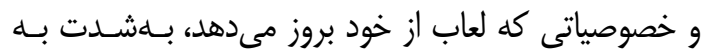

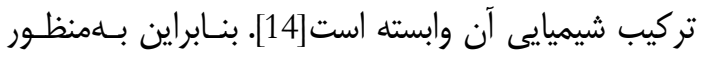
شناسايى كمى و كيفى تركيب شيميايى لعاب در كاشىهاى معرق صفوى در مصلاى تاريخى مشـهد و تعيـين عناصـر

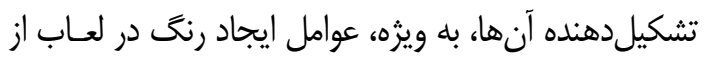

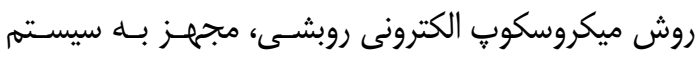
تجزيه يرتوى ايكس براكندهشه (SEM-EDX) اسـتفاده شد. براى اين منظور از انواع مختلف لعابهاى كاشىهـاى براى معرق اصيل بنا، به رنخهاى مختلف، شامل: لعـاب سـفيد،

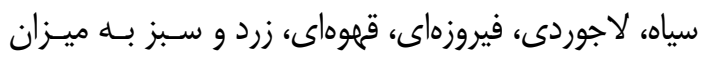

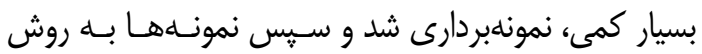

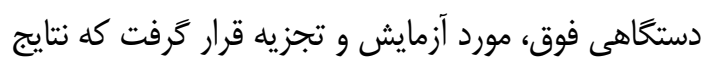
آن به شرح زير است: بررسى طيف بهدستآمده از تجزيـه عنصـرى لعـاب

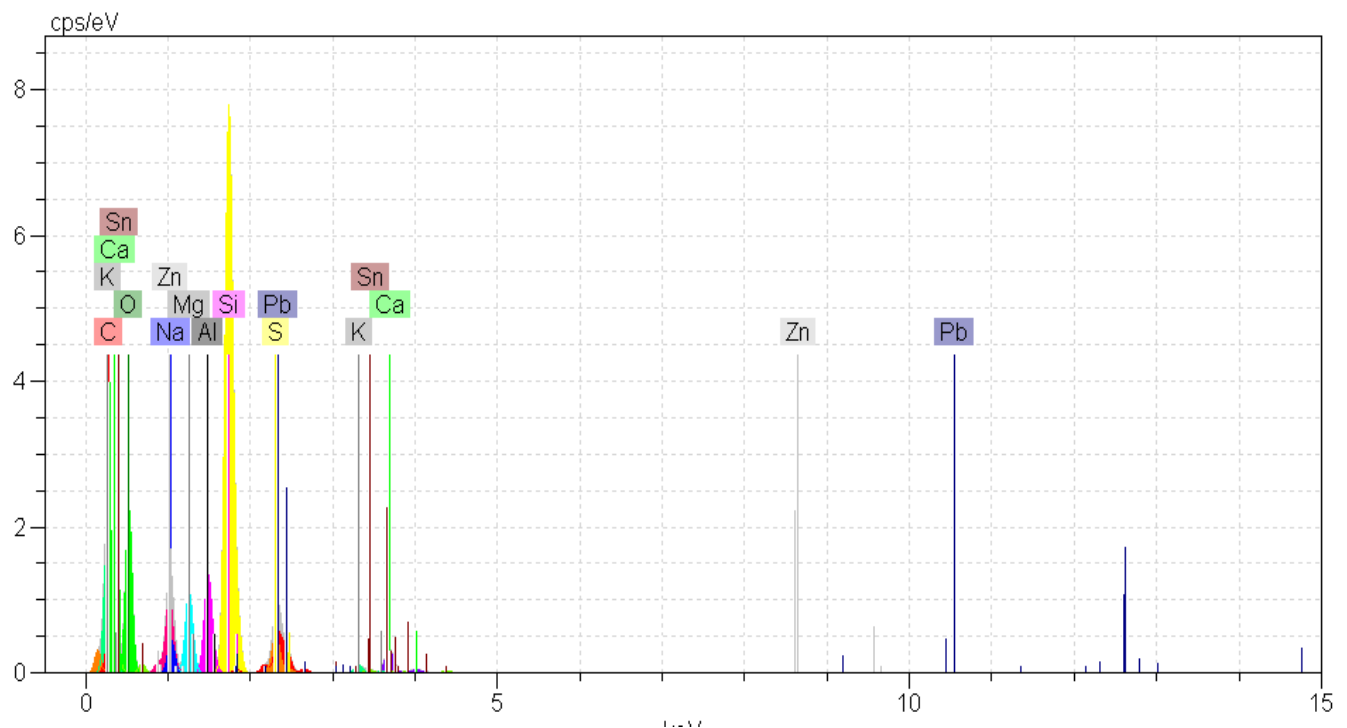

شكل 9: طيف تجزيه عنصرى لعاب كاشى سفيدرنح به روش SEM-EDX

Fig; 9: Elemental analysis spectrum of the white glaze by SEM-EDX method 


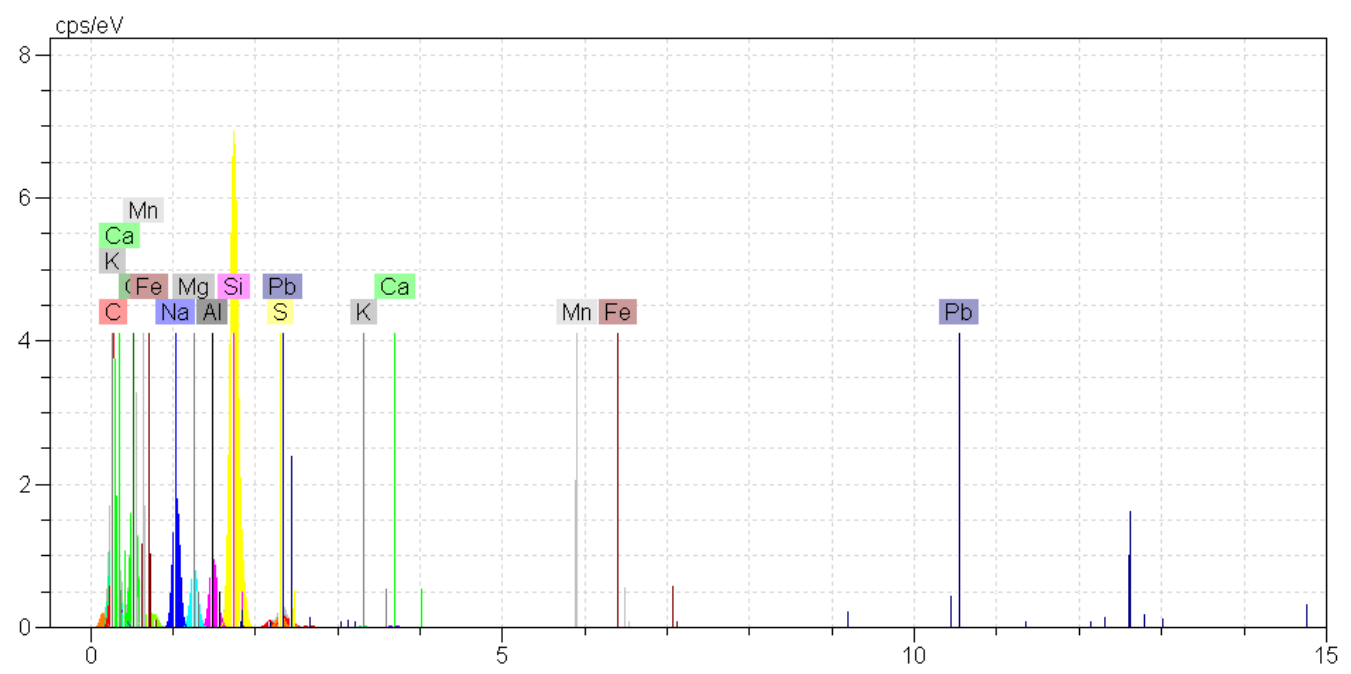

شكل • (: طيف تجزيه عنصرى لعاب كاشى سياهنگ به روش SEM-EDX

Fig; 10: Elemental analysis spectrum of the black glaze by SEM-EDX method

براى ايجاد رنغ آبى لاجوردى در كاشىها، استفاده شـده

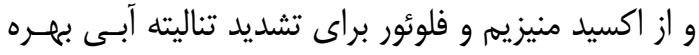

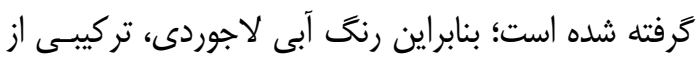

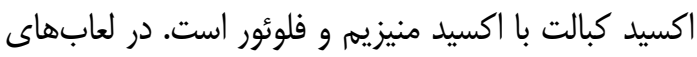

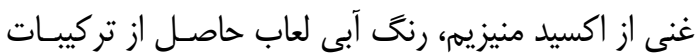

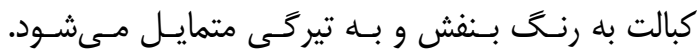

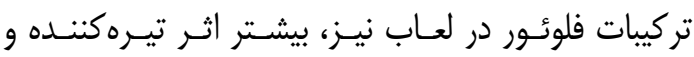

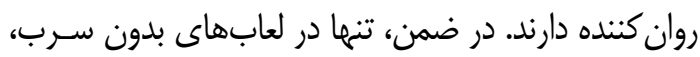

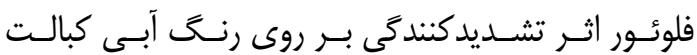

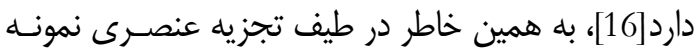

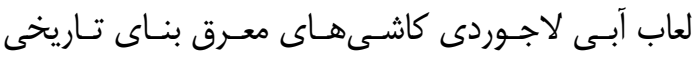
مصلاى مشهرد نيز، تركيب لعاب فاقد اكسيد سرب است و

جدول سا: نتايج تجزيه عنصرى نمونه لعاب كاشى آبى لاجوردى Table 3: Elemental analysis results of the blue glaze

\begin{tabular}{|c|c|c|}
\hline $\begin{array}{c}\text { درصد اتمىى } \\
\text { Atomic percent } \\
\text { A\% }\end{array}$ & $\begin{array}{c}\text { درصد وزنى } \\
\text { weight percent } \\
\text { w\% }\end{array}$ & نام عنصر \\
\hline 14.52 & 12.11 & $\mathrm{Na}$ \\
\hline 8.22 & 7.27 & $\mathrm{Mg}$ \\
\hline 6.74 & 6.62 & $\mathrm{Al}$ \\
\hline 53.07 & 54.24 & $\mathrm{Si}$ \\
\hline 7.62 & 8.90 & $\mathrm{~S}$ \\
\hline 2.29 & 3.27 & K \\
\hline 2.22 & 3.23 & $\mathrm{Ca}$ \\
\hline 0.27 & 0.54 & $\mathrm{Fe}$ \\
\hline 0.21 & 0.44 & Co \\
\hline 4.75 & 3.29 & $\mathrm{~F}$ \\
\hline
\end{tabular}

جدول r: نتايج تجزيه عنصرى نمونه لعاب كاشى سياهرنى Table 2: Elemental analysis results of the black glaze

\begin{tabular}{|c|c|c|}
\hline $\begin{array}{c}\text { درصد اتمىى } \\
\text { Atomic percent } \\
\text { A\% }\end{array}$ & $\begin{array}{c}\text { درصد وزنى } \\
\text { weight percent } \\
\text { w\% }\end{array}$ & نام عنصر \\
\hline 21.09 & 16.89 & $\mathrm{Na}$ \\
\hline 8.09 & 6.83 & $\mathrm{Mg}$ \\
\hline 8.34 & 7.81 & $\mathrm{Al}$ \\
\hline 57.43 & 56.16 & $\mathrm{Si}$ \\
\hline 1.77 & 1.95 & $\mathrm{~S}$ \\
\hline 0.16 & 0.20 & $\mathrm{~K}$ \\
\hline 0.45 & 0.61 & $\mathrm{Ca}$ \\
\hline 1.32 & 2.50 & $\mathrm{Mn}$ \\
\hline 0.53 & 1.16 & $\mathrm{Fe}$ \\
\hline 0.82 & 5.82 & $\mathrm{~Pb}$ \\
\hline
\end{tabular}

(Table 2

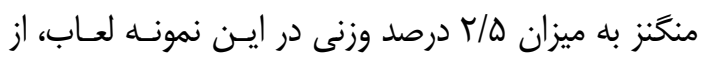

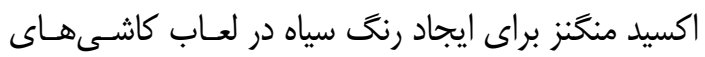

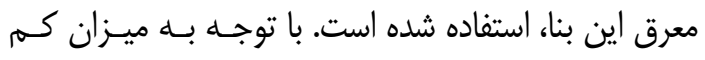

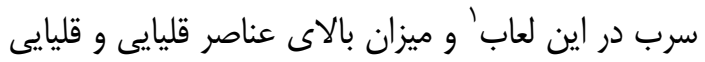

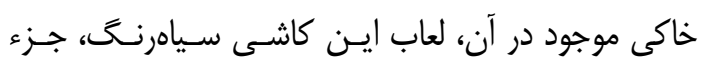
لعابهاى سرب قليايى است [15].

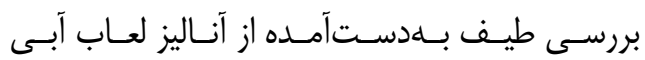
لاجوردى به روش SEM-EDX (شـكل II- (Fig; 11) و

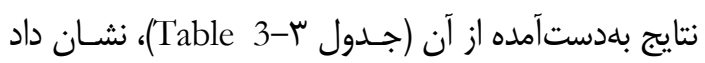

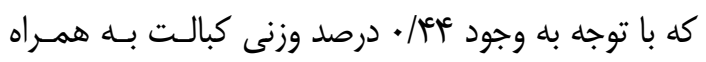

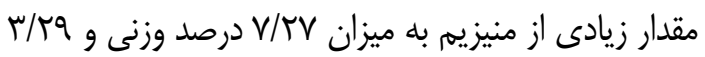
درصد وزنى، فلوئور در اين نمونه لعـاب، از اكسـيد كبالـ 


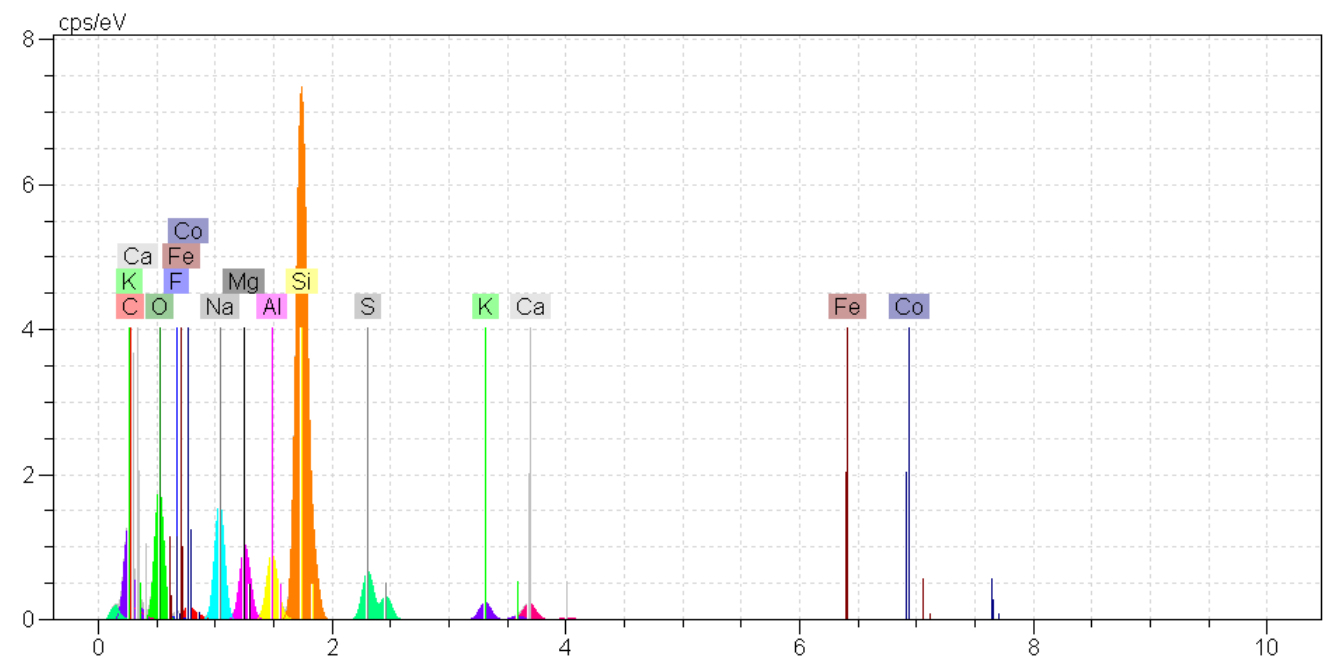

شكل 1) طيف آناليز عنصرى لعاب كاشى آبى لاجوردى به روش SEM-EDX

Fig; 11: Elemental analysis spectrum of the blue glaze by SEM-EDX method

وزنى در اين نمونه لعاب، از اكسيد مس براى ايجاد رنـــ

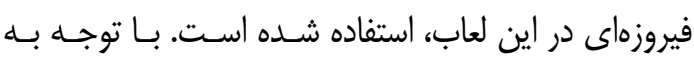

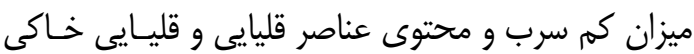

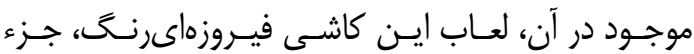
ل لعابهاى قليايى است[15]. بررسى طيف بهدست آمده از تجزيه عنصـرى لعـاب

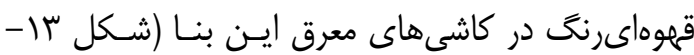

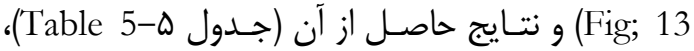

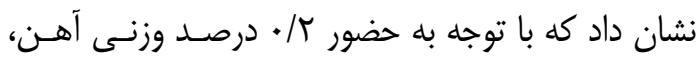

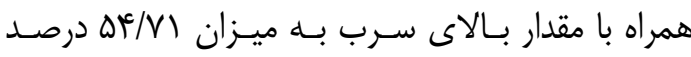

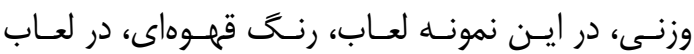

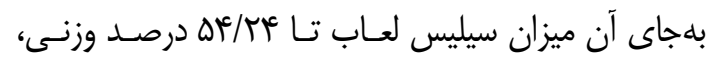

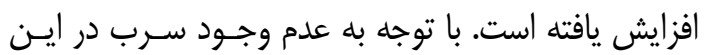

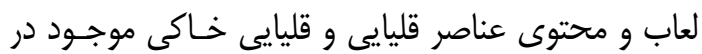

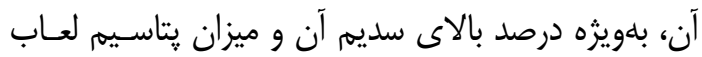

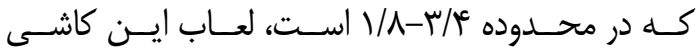
لاجوردى لانگ، جزء لعابهاى قليايى است [15].

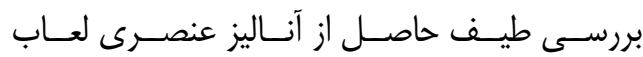

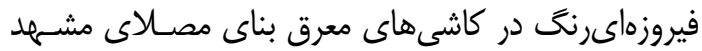

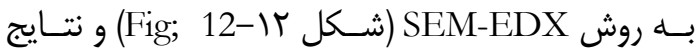

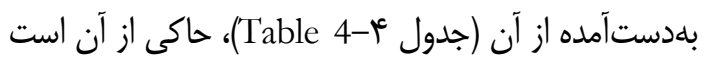

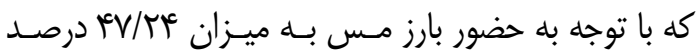

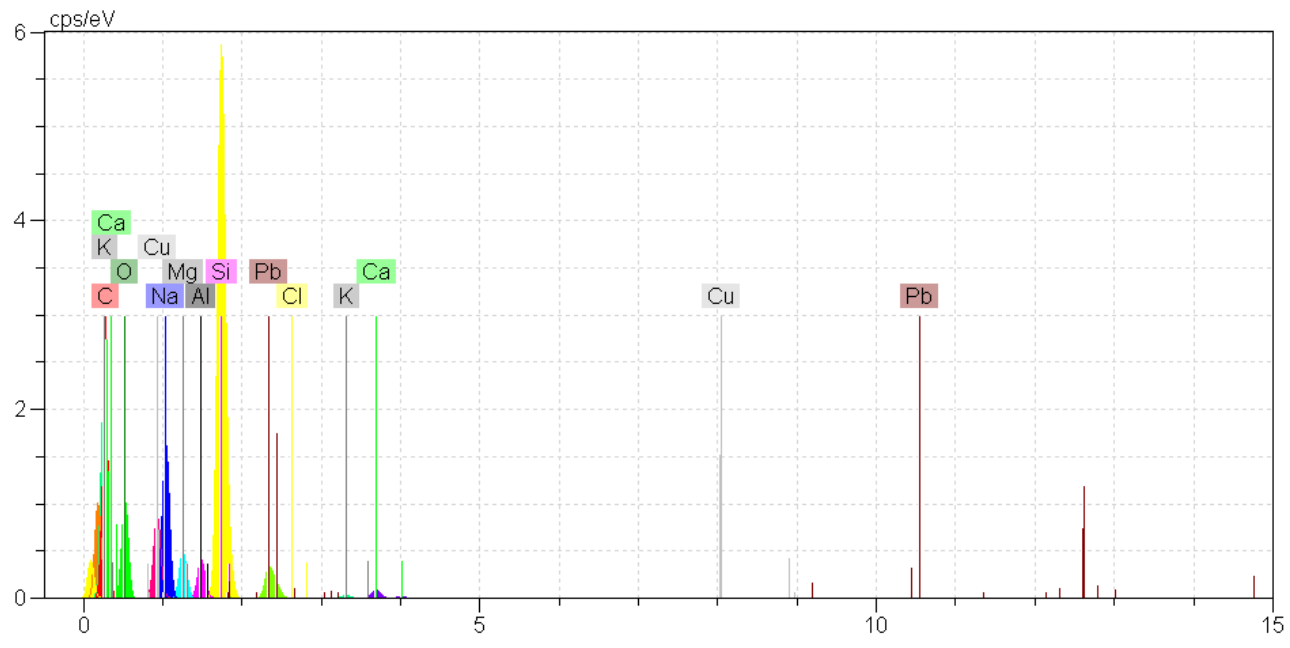

شكل rا: طيف تجزيه عنصرى لعاب كاشى فيروزهاىرنح به روش SEM-EDX

Fig; 12: Elemental analysis spectrum of the turquoise glaze by SEM-EDX method 


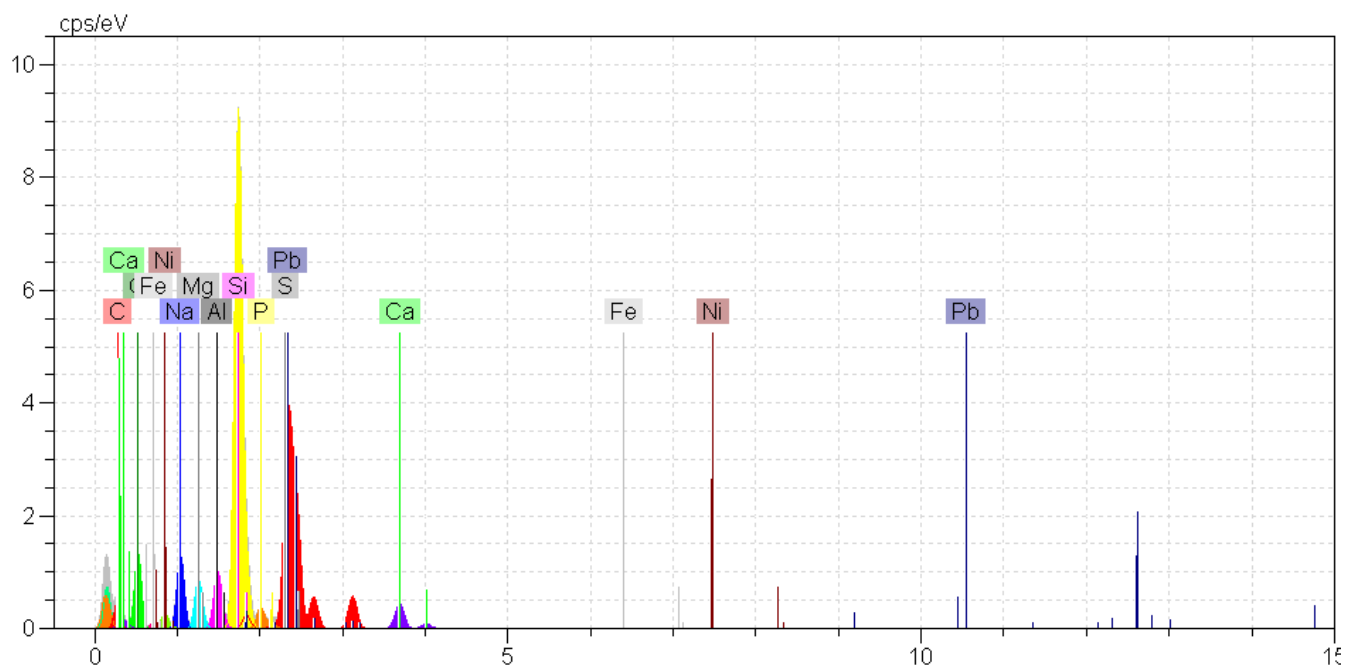

سا: طيف تجزيه عنصرى لعاب كاشى قهوماىرنى به روش SEM-EDX

Fig; 13: Elemental analysis spectrum of the brown glaze by SEM-EDX method

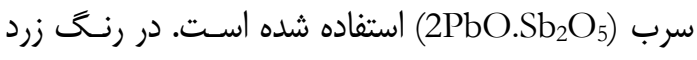
آنيموانات سرب، آنتيموان با سرب لعاب، تركيب و تشـكيل

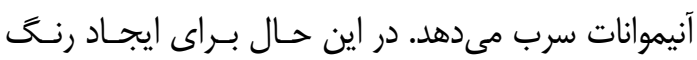
زرد، بايستى لعاب موردنظر غنـى از سـرب باشـــ، زيــرا در

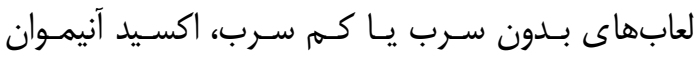

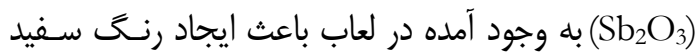

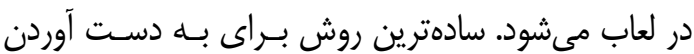
رنخ زرد، در هنين حـالتى، افـزودن مقـــارى آنتيموانـات

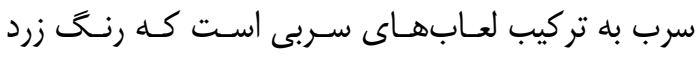
يررنغ زيبايى ايجـاد مسىكنــ[16]. آنتيموانـات سـرب از

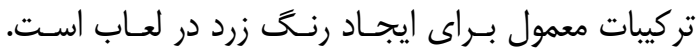
حضور مقاديرى از اكسيد سرب و آلومينيوم باعث ثبـات و و

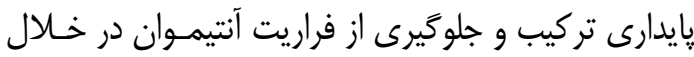

جدول ه: نتايج تجزيه عنصرى نمونه لعاب كاشى قهوهاىرنى Table 5: Elemental analysis results of the brown glaze

\begin{tabular}{|c|c|c|}
\hline $\begin{array}{c}\text { درصد اتمى } \\
\text { Atomic percent } \\
\text { A\% }\end{array}$ & $\begin{array}{c}\text { درصد وزنى } \\
\text { weight percent } \\
\text { W\% }\end{array}$ & نام عنصر \\
\hline 10.78 & 4.68 & $\mathrm{Na}$ \\
\hline 6.27 & 2.88 & $\mathrm{Mg}$ \\
\hline 6.55 & 3.33 & $\mathrm{Al}$ \\
\hline 54.4 & 28.84 & $\mathrm{Si}$ \\
\hline 3.24 & 1.88 & $\mathrm{P}$ \\
\hline 4.54 & 3.43 & $\mathrm{Ca}$ \\
\hline 0.18 & 0.20 & $\mathrm{Fe}$ \\
\hline 0.01 & 0.02 & $\mathrm{Ni}$ \\
\hline 13.99 & 54.71 & $\mathrm{~Pb}$ \\
\hline
\end{tabular}

جدول ثا: نتايج تجزيه عنصرى نمونه لعاب كاشى فيروزهاىرنى Table 4: Elemental analysis results of the turquoise glaze

\begin{tabular}{|c|c|c|}
\hline $\begin{array}{c}\text { درصد اتمى } \\
\text { Atomic percent } \\
\text { A\% A\%At\% }\end{array}$ & $\begin{array}{c}\text { درصد وزنى } \\
\text { weight percent } \\
\text { w \% }\end{array}$ & $\begin{array}{l}\text { نام عنصر } \\
\text { Element }\end{array}$ \\
\hline 17.40 & 10.25 & $\mathrm{Na}$ \\
\hline 4.06 & 2.57 & $\mathrm{Mg}$ \\
\hline 3.05 & 2.06 & $\mathrm{Al}$ \\
\hline 42.48 & 3.54 & $\mathrm{Si}$ \\
\hline 0.67 & 0.64 & $\mathrm{~K}$ \\
\hline 2.48 & 2.52 & $\mathrm{Ca}$ \\
\hline 29.03 & 47.24 & $\mathrm{Cu}$ \\
\hline 0.79 & 4.13 & $\mathrm{~Pb}$ \\
\hline
\end{tabular}

كاشى هاى معرق مصلاى تاريخى مشهلد، حاصل تركيبى

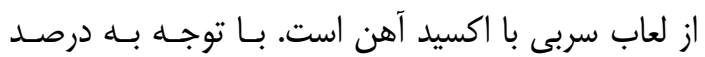

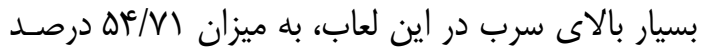

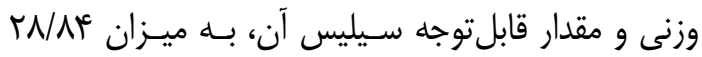

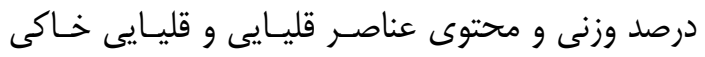

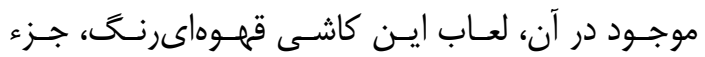
لعابهاى سربى است [15]. بررسى طيـف حاصـل از تجزيـه لعـاب زردرنــ در كاشىهاى معرق اين بنا بـه روش SEM-EDX fFig; 14-14) و نتايج بهدستآمده از تجزيه عنصرى لعاب در كاشىهاى زردرنخ (جدول 9-6 Table)، نشاندهنـــ

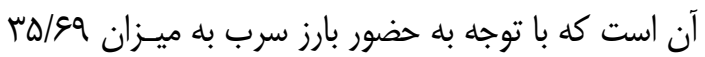

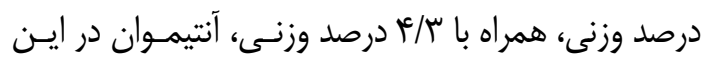

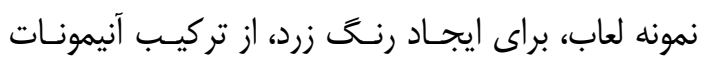




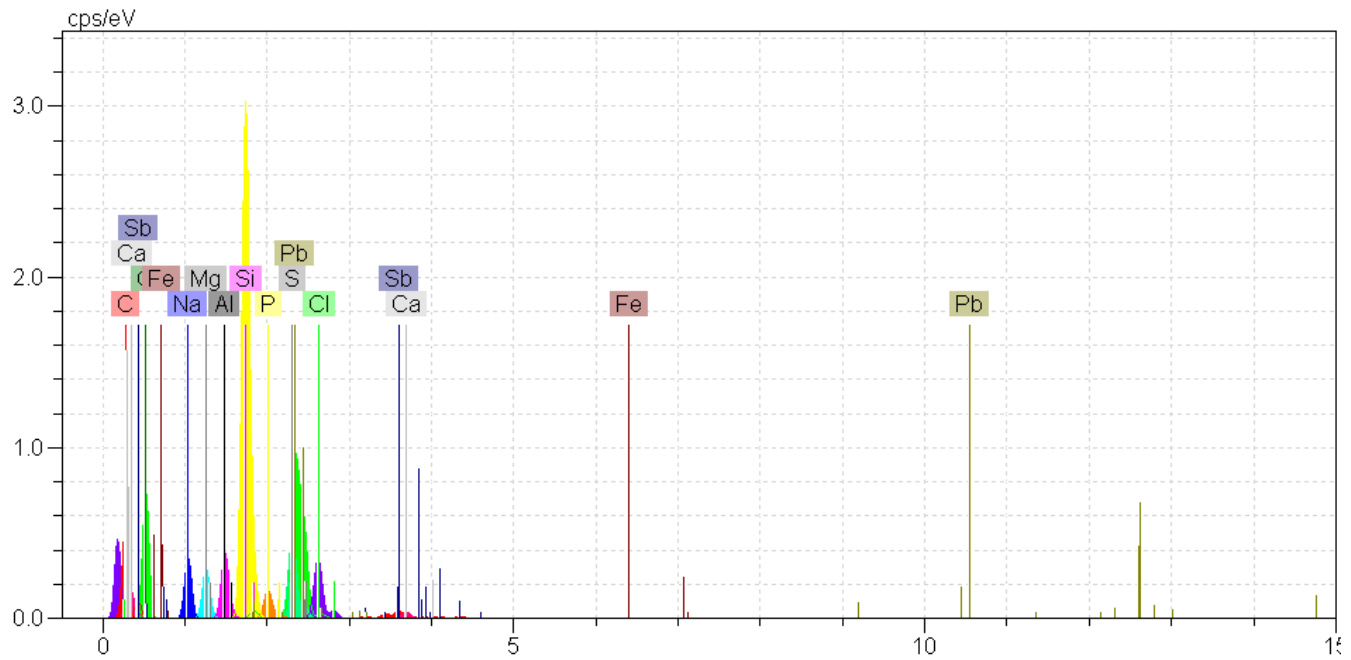

شكل ثا(: طيف تجزيه عنصرى لعاب كاشى زردرنخ به روش SEM-EDX

Fig; 14: Elemental analysis spectrum of the yellow glaze by SEM-EDX method

عمل تكليس مىشود[17]. با توجه به ميزان بالاى سرب در اين لعاب؛ يعنى وף/هّ درصد وزنى و محتوى عناصر قليايى و قليايى خاكى موجود در آن، لعاب اين كاشى زرد رنغ، جزء لعابهاى سربى است[15].

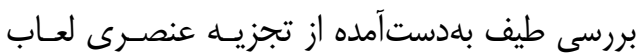
سبزرنخ بــاه روش SEM-EDX (شـكل ها (Fig; 15) و

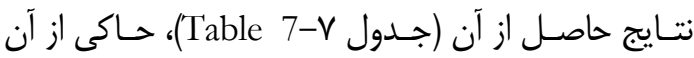
است كه با توجه به حضور

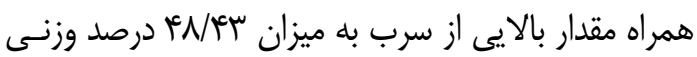
در اين لعاب، از اكسيد مس براى ايجاد رنغ سبز در ايـن
جدول ؤ نتايج تجزيه عنصرى نمونه لعاب كاشى زردرنگ Table 6: Elemental analysis results of the yellow glaze

\begin{tabular}{|c|c|c|}
\hline $\begin{array}{c}\text { درصد اتمى } \\
\text { Atomic percent } \\
\text { A\% }\end{array}$ & $\begin{array}{c}\text { درصد وزنى } \\
\text { weight percent } \\
\text { w\% }\end{array}$ & نام عنصر \\
\hline 7.90 & 4.15 & $\mathrm{Na}$ \\
\hline 5.34 & 2.95 & $\mathrm{Mg}$ \\
\hline 6.18 & 3.80 & $\mathrm{Al}$ \\
\hline 45.99 & 29.48 & $\mathrm{Si}$ \\
\hline 3.34 & 2.37 & $\mathrm{P}$ \\
\hline 8.85 & 6.50 & $\mathrm{~S}$ \\
\hline 7.07 & 3.22 & $\mathrm{Cl}$ \\
\hline 1.28 & 1.17 & $\mathrm{Ca}$ \\
\hline 4.95 & 6.30 & $\mathrm{Fe}$ \\
\hline 1.55 & 4.30 & $\mathrm{Sb}$ \\
\hline 7.51 & 35.69 & $\mathrm{~Pb}$ \\
\hline
\end{tabular}

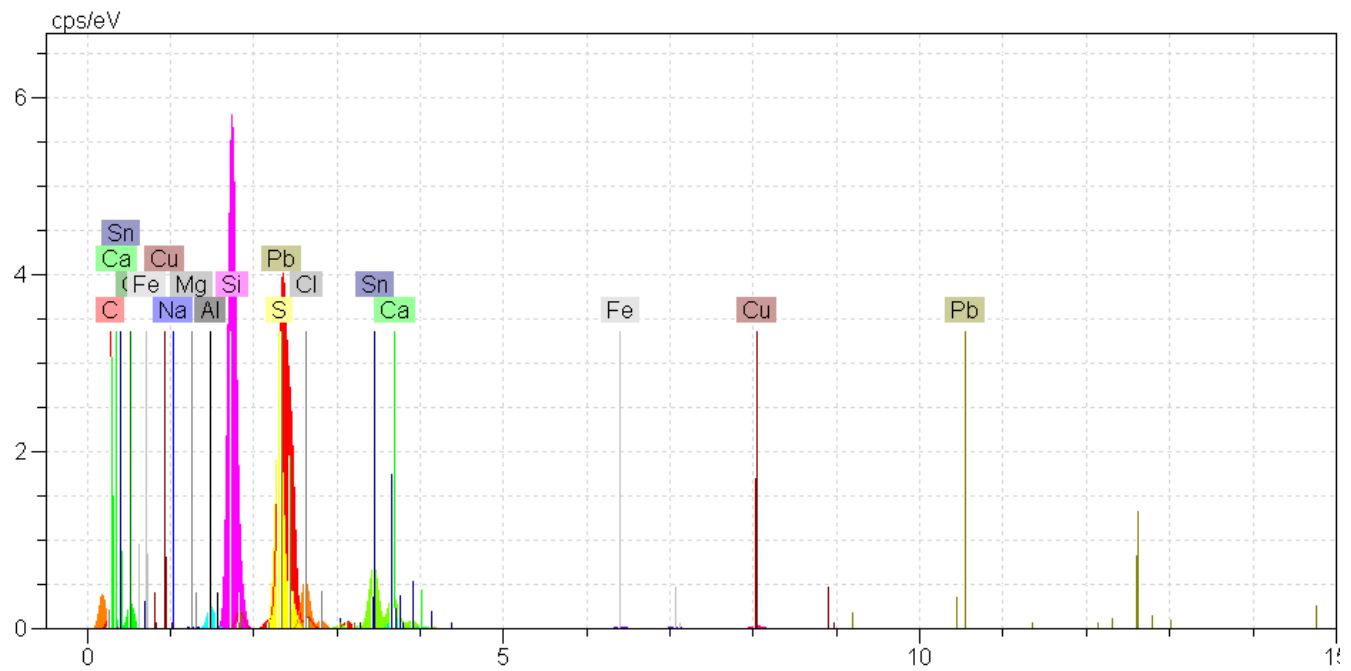

شكل ها: طيف تجزيه عنصرى لعاب كاشى سبزرنخ به روش SEM-EDX

Fig; 15: Elemental analysis spectrum of the green glaze by SEM-EDX method 
مىرسد كه در تركيب لعاب ايـن كاشـىهـا از سـيليس و

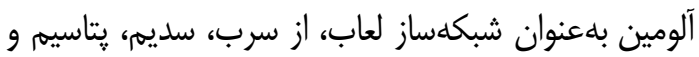

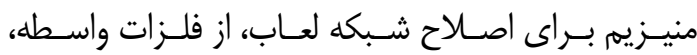
همجِون: منَخنز، آهن، مس و كبالت بلهعنوان عامل ايجـاد

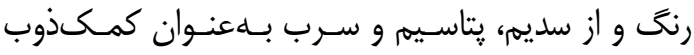

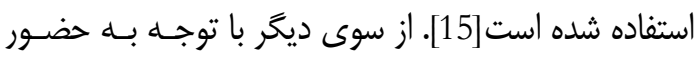

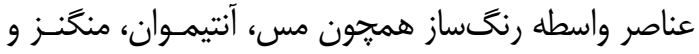
كبالت در تركيب شيميايى لعاب كاشىها و نإيايدارى ايسن

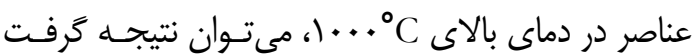

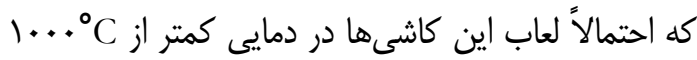
يخته شده است[14]. نتايج حاصـل از مطالعـه و تجزيـهـ عنصــرى تركيـب

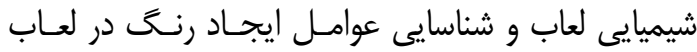

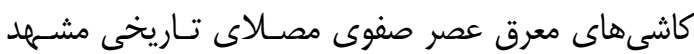

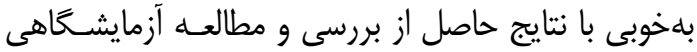

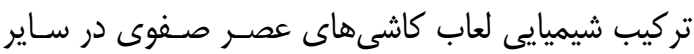

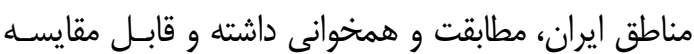
است (جدول 1Table 8- (T).
جدول У: نتايج تجزيه عنصرى نمونه لعاب كاشى سبزرنگ

Table 7: Elemental analysis results of the green glaze

\begin{tabular}{|c|c|c|}
\hline $\begin{array}{c}\text { درصد اتمى } \\
\text { Atomic percent } \\
\text { A\% }\end{array}$ & $\begin{array}{c}\text { درصد وزنى } \\
\text { weight percent } \\
\text { w\% }\end{array}$ & نام عنصر \\
\hline 1.98 & 0.83 & $\mathrm{Al}$ \\
\hline 43.58 & 19.02 & $\mathrm{Si}$ \\
\hline 20.47 & 10.20 & $\mathrm{~S}$ \\
\hline 5.70 & 3.14 & $\mathrm{Cl}$ \\
\hline 1.62 & 1.01 & $\mathrm{Ca}$ \\
\hline 1.41 & 1.22 & $\mathrm{Fe}$ \\
\hline 3.02 & 2.98 & $\mathrm{Cu}$ \\
\hline 7.11 & 13.13 & Sn \\
\hline 15.03 & 48.43 & $\mathrm{~Pb}$ \\
\hline
\end{tabular}

نمونه استفاده شده است؛ بنابراين رنخ سبز در اين نمونه لعاب كاشى معرق، تركيبى از اكسيد مس با لعاب سربى

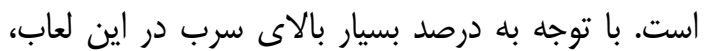

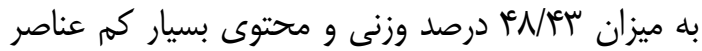

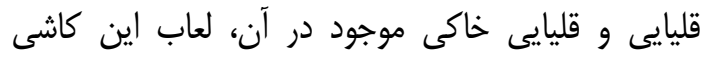
سبزرنگَ، از نوع لعابهاى سربى است [15].

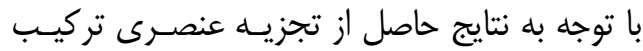

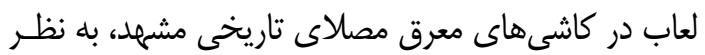

جدول م: مقايسه نتايج حاصل از تجزيه عنصرى لعاب كاشىهاى عصر صفوى مصلاى تاريخى مشهد با نتايج بهدستآمده توسط ساير محققين در

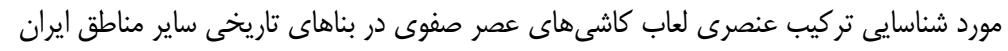

Table 8: Comparison of Elemental analysis results of tile-making in the Safavid era of Mashhad historical Musalla with the results obtained by other scholars on the identification of the elemental composition of the glaze of Safavid era tiles in the monuments of other regions of Iran.

\begin{tabular}{|c|c|c|c|c|c|c|}
\hline $\begin{array}{l}\text { This study, } \\
2018\end{array}$ & $\begin{array}{l}\text { Mishmastnehi } \\
\text { \& Holakooei, } \\
2015 \\
\end{array}$ & $\begin{array}{l}\text { Holakooei, } \\
2013\end{array}$ & $\begin{array}{l}\text { Soltanzadeh, } \\
\text { et al, } 2009\end{array}$ & $\begin{array}{c}\text { Abed Esfahani \& } \\
\text { Zahedian, } 2007\end{array}$ & $\begin{array}{c}\text { Lamehi-Rachti, et } \\
\text { al, } 2001\end{array}$ & $\begin{array}{c}\text { نمونههاى لعاب } \\
\text { Glaze samples }\end{array}$ \\
\hline $\begin{array}{l}\text { قلع و سرب } \\
\text { Tin \& lead }\end{array}$ & $\begin{array}{c}\text { قلع و سرب } \\
\text { Tin \& lead }\end{array}$ & $\begin{array}{c}\text { قلع و سرب } \\
\text { Tin \& lead }\end{array}$ & & & & $\begin{array}{c}\text { لعاب كاشى سفيدرنگ } \\
\text { the white glaze }\end{array}$ \\
\hline $\begin{array}{c}\text { منزخese } \\
\text { Manganese }\end{array}$ & & $\begin{array}{c}\text { منگ } \\
\text { Manganese } \\
\end{array}$ & & & $\begin{array}{c}\text { منزخ } \\
\text { Manganese } \\
\end{array}$ & $\begin{array}{c}\text { لعاب كاشى سيامرنگ } \\
\text { the black glaze }\end{array}$ \\
\hline $\begin{array}{c}\text { كبالت } \\
\text { cobalt(II) } \\
\end{array}$ & $\begin{array}{c}\text { كبالت } \\
\text { cobalt(II) } \\
\end{array}$ & $\begin{array}{c}\text { كبالت } \\
\text { cobalt(II) } \\
\end{array}$ & $\begin{array}{c}\text { كبالت } \\
\text { cobalt(II) }\end{array}$ & & $\begin{array}{c}\text { كبالت } \\
\text { cobalt(II) } \\
\end{array}$ & $\begin{array}{c}\text { لعاب كاشى لاجوردىرنى } \\
\text { the blue glaze }\end{array}$ \\
\hline $\begin{array}{c}\text { مس } \\
\text { Copper }\end{array}$ & & $\begin{array}{c}\text { مس } \\
\text { Copper }\end{array}$ & & مس & $\begin{array}{c}\text { مس } \\
\text { Copper }\end{array}$ & 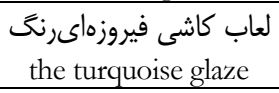 \\
\hline $\begin{array}{l}\text { آهن } \\
\text { Iron }\end{array}$ & & $\begin{array}{c}\text { منگنز و آهن } \\
\text { Manganese \& } \\
\text { Iron } \\
\end{array}$ & & & & $\begin{array}{l}\text { لعاب كاشى قهوماىرنغ } \\
\text { the brown glaze }\end{array}$ \\
\hline $\begin{array}{c}\text { آنتيموان و سرب } \\
\text { Lead \& } \\
\text { Antimony } \\
\end{array}$ & & $\begin{array}{c}\text { قلع و سرب } \\
\text { Tin \& lead }\end{array}$ & آهن و سرب & سرب & $\begin{array}{l}\text { قلع و سرب } \\
\text { Tin \& lead }\end{array}$ & $\begin{array}{l}\text { لعاب كاشى زردرنخ } \\
\text { the yellow glaze }\end{array}$ \\
\hline $\begin{array}{c}\text { مس } \\
\text { Copper }\end{array}$ & & مس & & & & $\begin{array}{c}\text { لعاب كاشى سبزرنگ } \\
\text { the green glaze }\end{array}$ \\
\hline $\begin{array}{c}\text { قرن IV } \\
\text { 17th century }\end{array}$ & $\begin{array}{c}\text { قرن IV } \\
\text { 17th century }\end{array}$ & $\begin{array}{c}\text { قرن IV } \\
17^{\text {th }} \text { century }\end{array}$ & 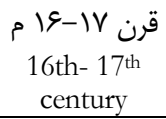 & $\begin{array}{c}\text { قرن IV } \\
17^{\text {th }} \text { century }\end{array}$ & 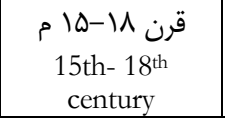 & $\begin{array}{l}\text { قدمت آثار موردمطالعه } \\
\text { Date of the sample }\end{array}$ \\
\hline
\end{tabular}


هوازدگى و خرد شدن سنگ مادر مولد خاك مورد استفاده

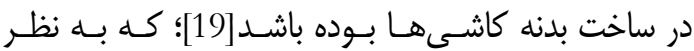

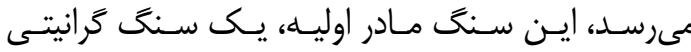
و و يا يك سنگ ريوليتى (Granite)

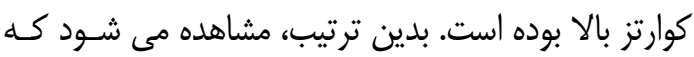

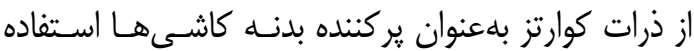
شده اسـت. اسـتفاده از ذرات كـوارتز ريزدانـه و كَشـهـدار همراه با كانىهـاى رسـى و آب يـس از ورز دادن، بـافتى آنى

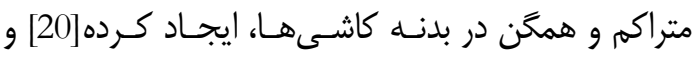

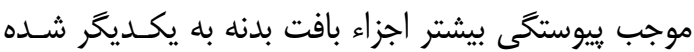

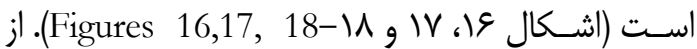
سوى ديخر، وجود مقادير زيـاد سـيليس در تركيـب بدنــه

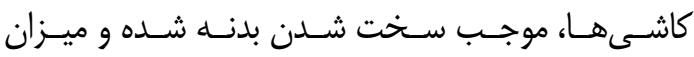
شكليذيرى آنها را تا حدى كم مى كند. در بين دانههاى كوارتز، خطوط شكستخى، ديده مىشود كه احتمالاً مربوط به زمان ساخت بدنه كاشىها است (شكل عا-Fig; 16). اين خطوط، اكسيدها و وان أنمان فلدسياتهايى هستند كه جانشين فضاهاى خالى موجود شدهاند و به شكل خطوط شكستخى درآمدهاند. به نظر هائ هائ مىرسد كه در هنخام يخت بدنه كاشىها در كوره، اكسيدهاى آهن موجود در بدنه و لعاب كاشى به سمت بـ بانه بلورهاى كانى موجود در بدنه، حركت كرده و جذب دانب فضاهاى خالى آنها شده و بلصورت خطوط شكستخى، كانىها را احاطه نمودهاست و يا اينكه اين خطوط، لهاك
F-r-r. مطالعه ساختارى بدنه كاشىهاى معرق به روش يتروگر افى سلى

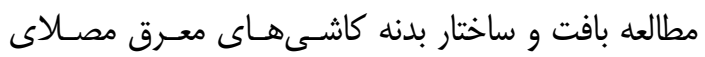

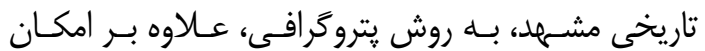

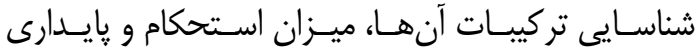

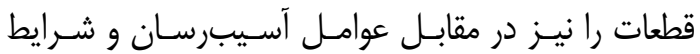

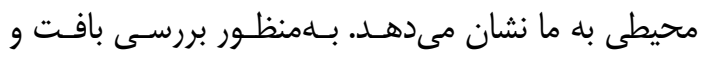
تركيب كانىشناسى بدنـه كاشـىهـاى معـرق صـفوى در

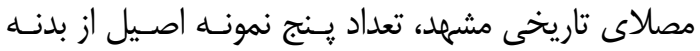

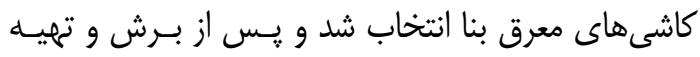

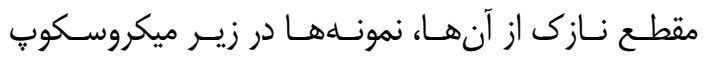

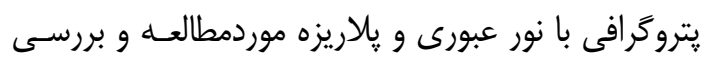
قرار كرفت. نتايج حاصل از بررسى و مطالعه ميكروسكويى بوريى بلنه كاشىهاى معرق صفوى به روش يتروگرافى به شحح

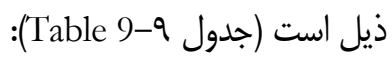
كوارتز (Quartz)، شاخصترين كانى قابلمشاهده در (جاتور مقاطع نازى تهيهشده از نمونههاى بدنه كاشىهاى معرق مصلاى تاريخى مشهد است. اين كانى به شكل بلورهاى

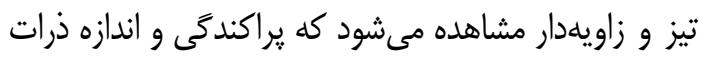

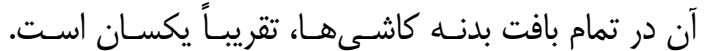

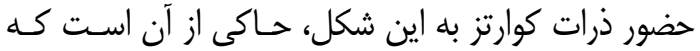

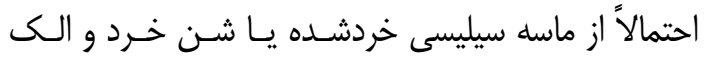
شده[18]، در بدنه كاشىهاى معرق اسـتفاده شـــ اسـت؛

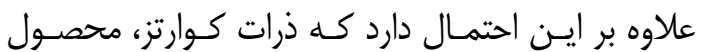

جدول ج: نتايج مطالعه ساختارى و تر كيب كانىشناسى بدنه كاشىهاى معرق مصلاى مشهد به روش يتروگرافى

Table 9: The results of structural study and mineralogical composition of the body mosaic tiles of Mashhad historical Musalla by petrography method

\begin{tabular}{|c|c|c|c|c|}
\hline $\begin{array}{c}\text { مشخصات ميكروسكويى } \\
\text { Microscopic specification }\end{array}$ & $\begin{array}{c}\text { Pرصد } \\
\text { Percent }\end{array}$ & $\begin{array}{c}\text { نام كانى } \\
\text { Mineral name }\end{array}$ & $\begin{array}{c}\text { نام گروه } \\
\text { Group name }\end{array}$ & $\begin{array}{c}\text { شماره نمونه } \\
\text { Sample number }\end{array}$ \\
\hline $\begin{array}{c}\text { PPL لكه سفيد در حالت } \\
\text { White spot in PPL mode }\end{array}$ & 1 & $\begin{array}{c}\text { مسكويت } \\
\text { Muscovite }\end{array}$ & $\begin{array}{l}\text { ميكاى سفيد } \\
\text { White mica }\end{array}$ & 1 \\
\hline $\begin{array}{l}\text { SPL لكه قهوهاى در حالت } \\
\text { Brown spot in SPL mode }\end{array}$ & $2-3$ & $\begin{array}{c}\text { هورنبلند } \\
\text { Hornblende }\end{array}$ & $\begin{array}{c}\text { آمفيبول } \\
\text { Amphibole }\end{array}$ & 2 \\
\hline $\begin{array}{l}\text { SPL نقاط ريز قهوهاى در حالت } \\
\text { Tiny brown spot in SPL }\end{array}$ & $2-3$ & $\begin{array}{l}\text { بيوتيت } \\
\text { Biotite }\end{array}$ & $\begin{array}{l}\text { ميكاى قهوlow } \\
\text { Brown mica }\end{array}$ & 3 \\
\hline $\begin{array}{l}\text { خاكسترىرنگ در حالتPPL } \\
\text { Gray color in PPL mode }\end{array}$ & $60-65$ & $\begin{array}{c}\text { كوارتز } \\
\text { Quartz }\end{array}$ & $\begin{array}{c}\text { كوارتز } \\
\text { Quartz }\end{array}$ & 4 \\
\hline $\begin{array}{l}\text { خاكسترىرنگ در حالتPPL } \\
\text { Gray color in PPL mode }\end{array}$ & $25-30$ & فلدسيار & فلدسيار & 5 \\
\hline
\end{tabular}

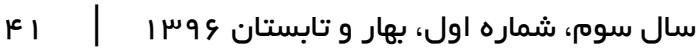




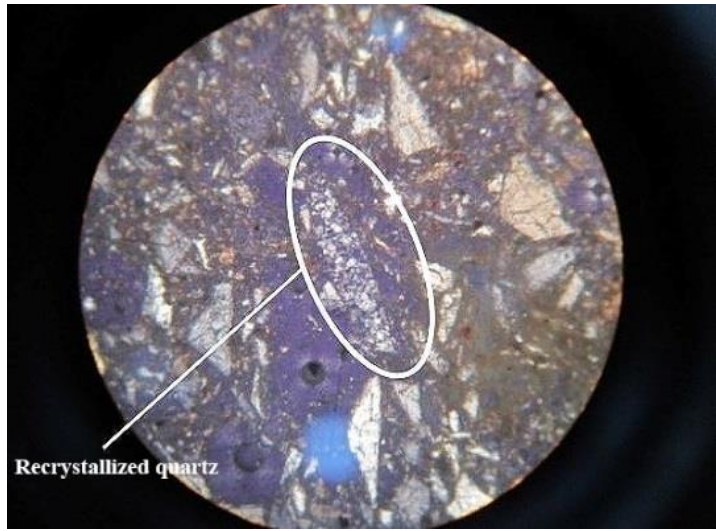

شكل VI ا: كوارتز باز تبلور شده، بزركنمايى 100X حالت PPL Fig; 17: Recrystallized quartz, 100x, PPL mode

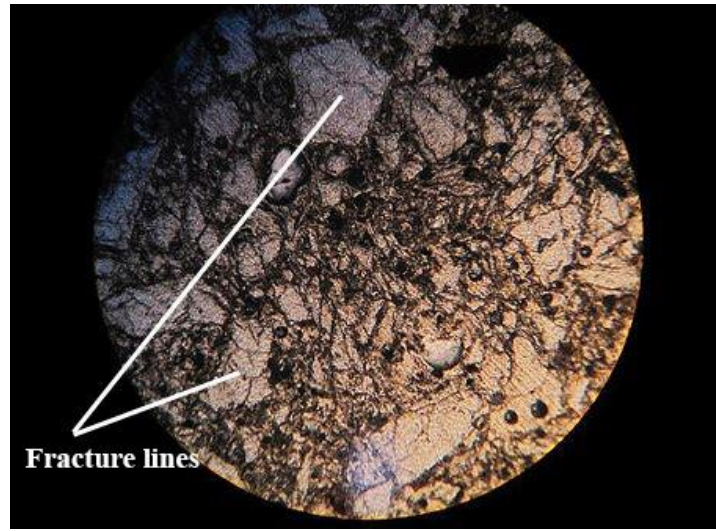

شكل عا: حضور ذرات كوارتز و خطوط شكستخى در بين آنها،

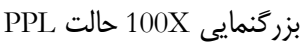

Fig; 16: The presence of quartz particles and fracture lines among them, 100x, PPL mode

احتمال دارد، حاصل شكستگى و ريزتر كهـاى موجـود در

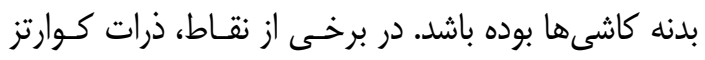

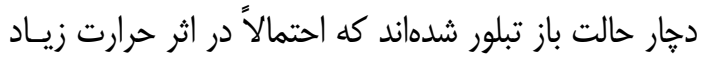

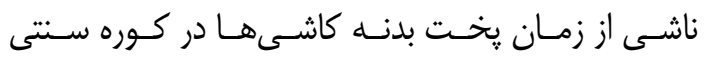

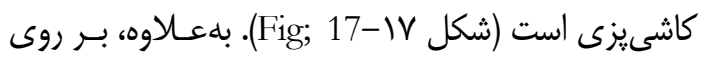

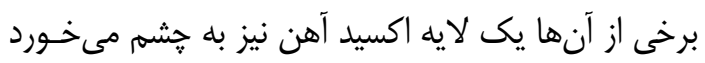

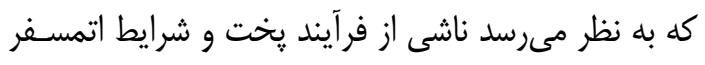
كوره باشد (شكل 11-18;

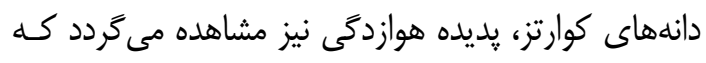
منجر به ورقه شدن سطح بدنه در نمونهها، شده است.

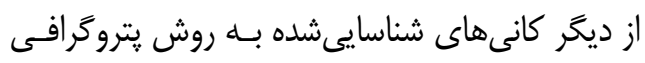
در مقاطع نازى حاصل از بدنه كاشىهاى معرق، فازهـاى

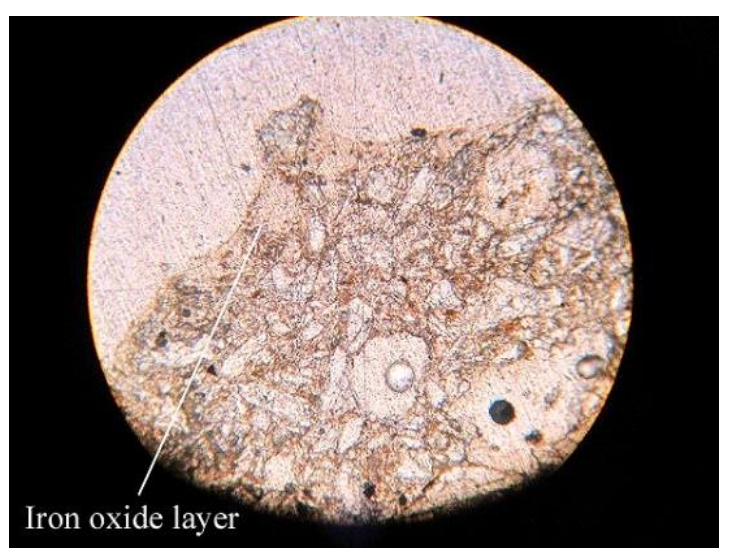

شكل \\: وجود لايه اكسيد آهن بر روى ذرات كوارتز، بزركنمايى حالت حالت PنL

Fig; 18: The presence of iron oxide layer on the quartz particles, 25x, PPL mode

سال سوم، شماره اول، بهار و تابستان و وسر 


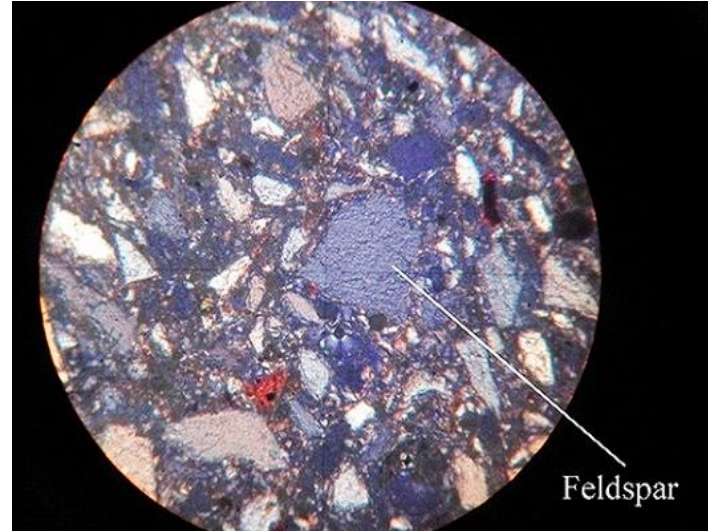

شكل آז: كانى فلدسيار بdصورت لكه خاكسترىرنگ، بزرگنمايى حالت PPL

Fig; 21: Feldspar mineral in to form a Gray blemish, 25x, PPL mode

اصلى تشكيلدهنده يوسته زمين است و خود عامل تشكيل دهنده كانىهاى رسى است؛ بنابراين همراه ساير كانىهاى رسى در تركيب بدنه كاشىها نيز ديده مىشود.

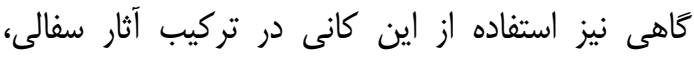

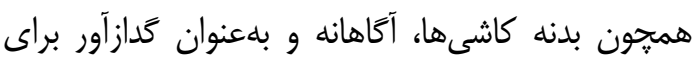

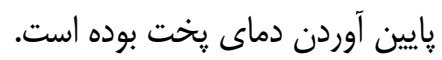

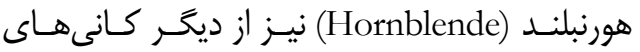
شناسايىشده در بدنه كاشىها بوده اسـت كـه بــهــورت

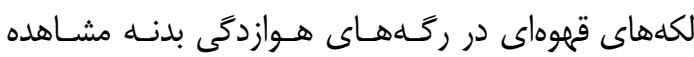

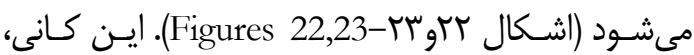

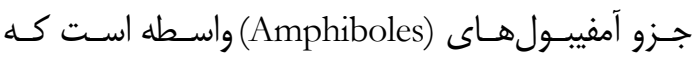

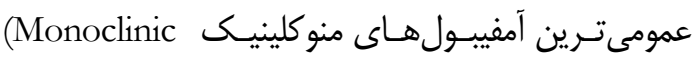
ا ا تشكيل مىدهند. Amphiboles)

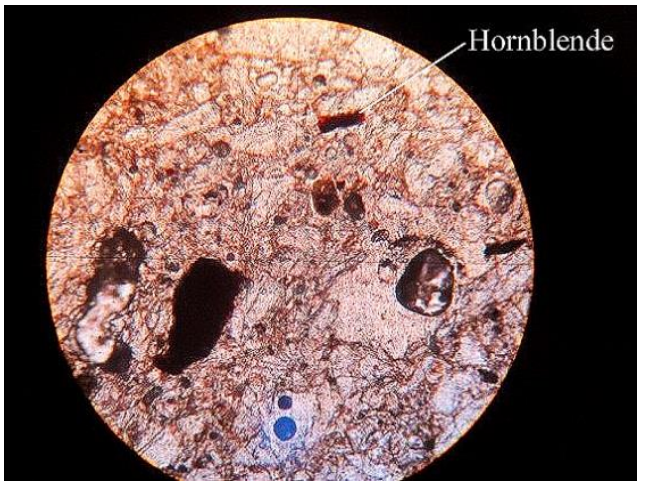

شكل سٓ: كانى هورنبلند و هوازدگى اطراف آن، بزرَنمايى 100X حالت XPL Fig; 23: Hornblende mineral and weathering around it, 100x, XPL mode

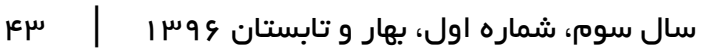

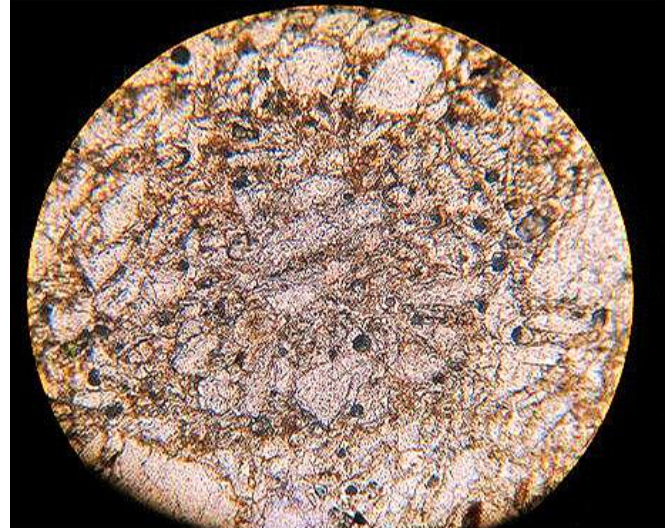

100X شكل · r: كانى بيوتيت بلصورت نقاط ريز قهوهاى، بزركنمايى حالت XPL

Fig; 20: Biotite mineral in to form a tiny brown spots, $100 \mathrm{x}$, XPL mode

رسى، اين كانىها به سهولت در تركيب بدنه كاشىها،

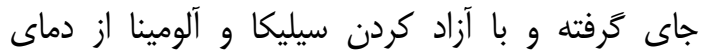

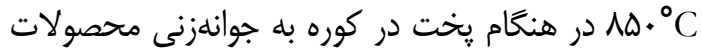

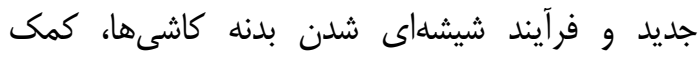

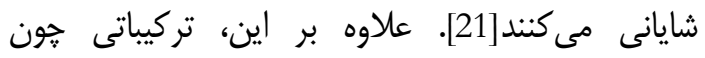

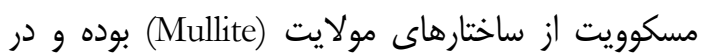
شرايط مناسب ازلحاظ دما، زمان و ماندگًارى، مىتواند به جوانهزنى مولايت منجر شود كه درنهايت، موجب افزايش دوام و استحكام بدنه كاشىها مىشود[22]. فلدسيار (Feldspar)، از ديخر كانىهاى شناسايیشده در مقاطع ميكروسكويى بدنه كاشىها است (شكل (Fig; 21- (F). حضور فلدسيارها تقريباً در تمامى سفالهاى تارئى إيخى، امرى اجتنابنايذير است؛ جراكه اين كانى، جزء تركيبات

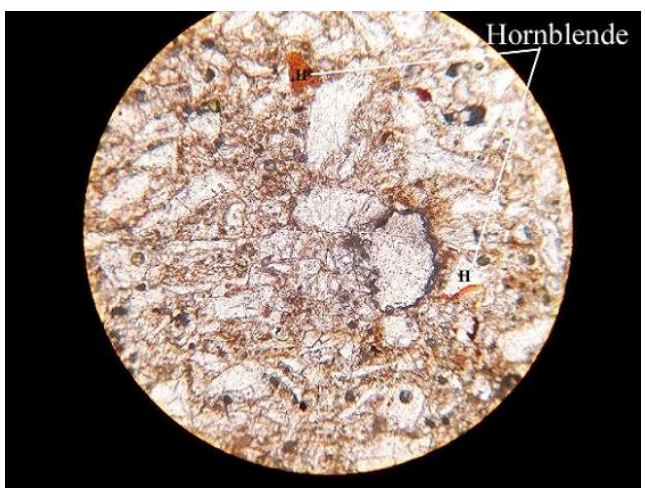

شكل זr: كانى هورنبلند، بزر كنمايى، 100X حالت XPL Fig; 22: Hornblende mineral, 100x, XPL mode 
هنغام خشك شدن آنها، استفاده شده است كـه حاصـل ه. نتيجه

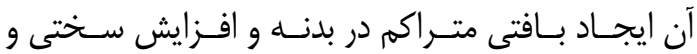

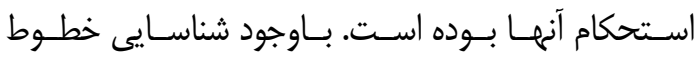

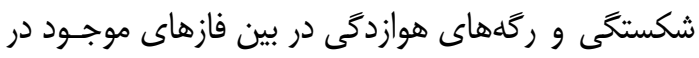

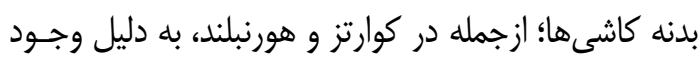

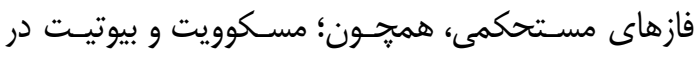

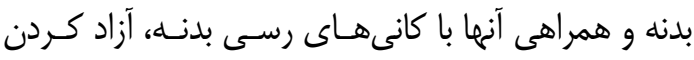

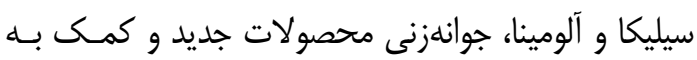

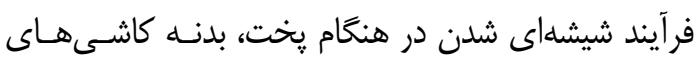

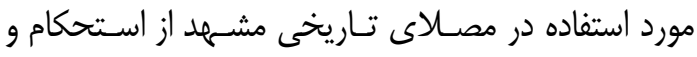
دوام نسبتاً خوبى برخوردار بوده است.

\section{سباسكَزارى}

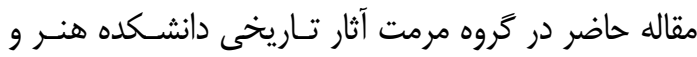
معمارى دانشخاه زابل انجام شده است كه در اين راسـتا از

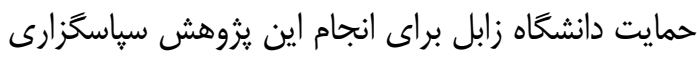

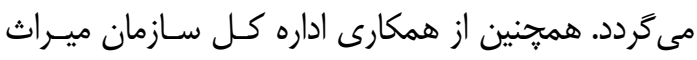

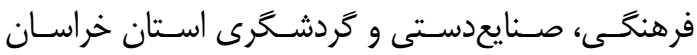

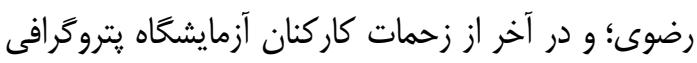

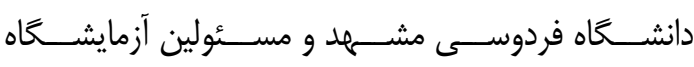

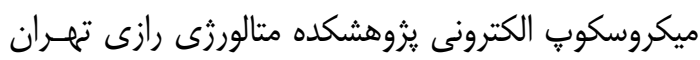
نيز صميمانه تشكر و قدردانى مى گرددر.

\section{يبىنوشتها}

ا. لعاب به كار رفته در كاشىها، بر اساس محتوى اكسـيد

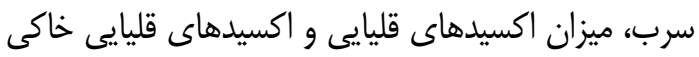

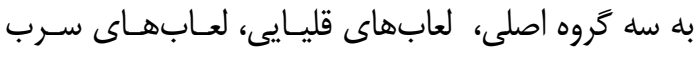

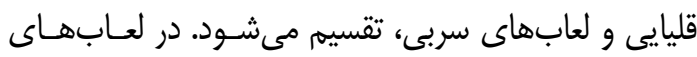

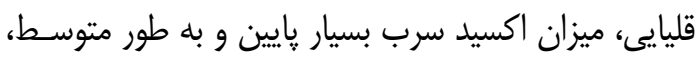

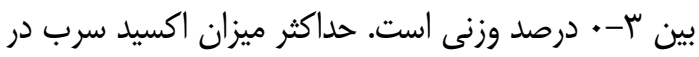

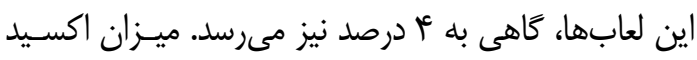

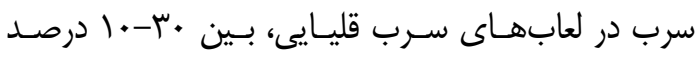

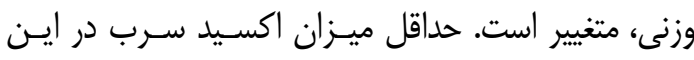

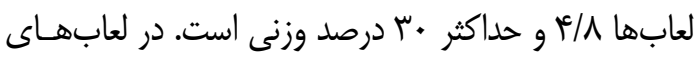

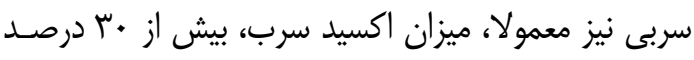

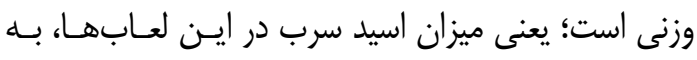

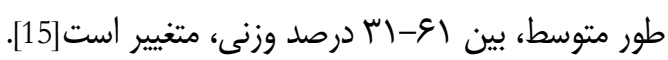

بررسى و مطالعـه آزمايشـخاهى تركيـب شـيميايى لعـاب

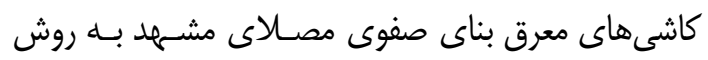

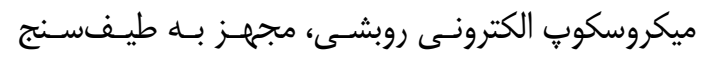
يراكنش انرزى يرتوى ايكس (SEM-EDX) نشـان داد

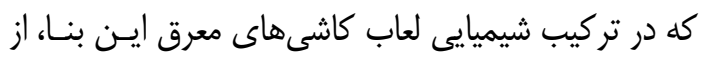

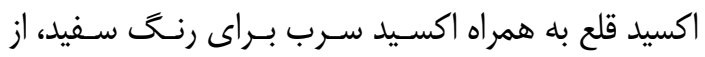

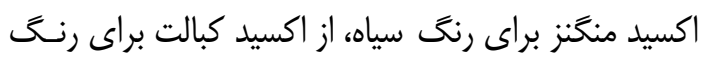

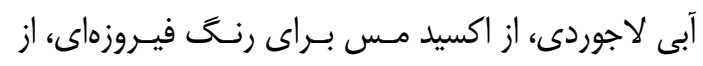

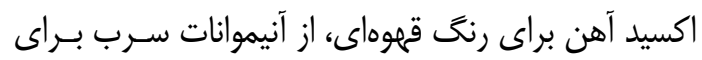

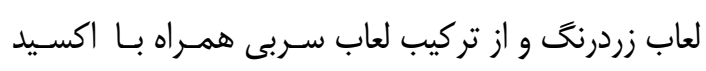

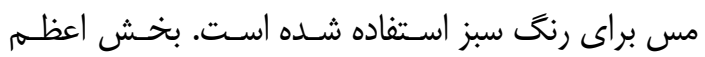

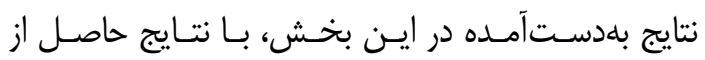

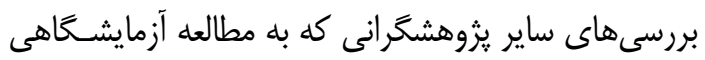
تر كيب شيميايى لعاب كاشىهاى عصر صفوى در بناهـاى

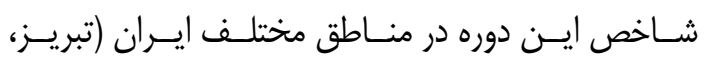

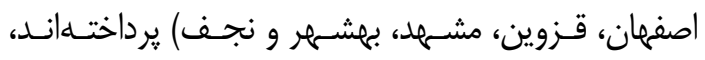

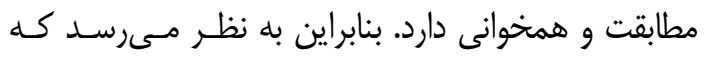

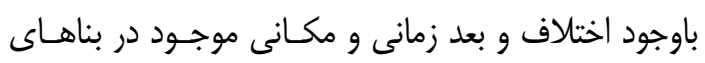

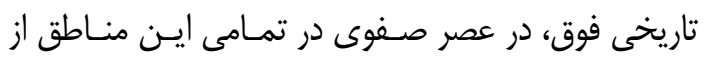

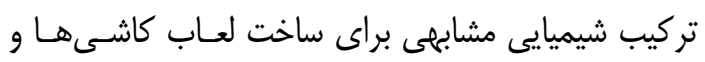

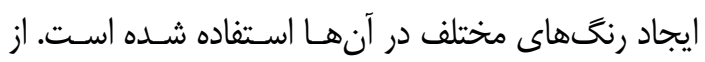
سوى ديكر، هرجند تفـاوتهـاى بسـيار جزئسى در نتـايج

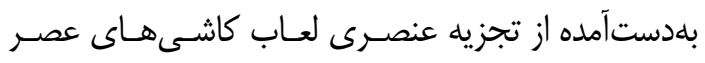

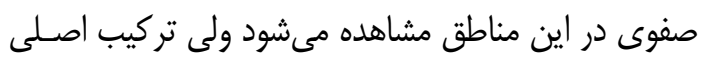

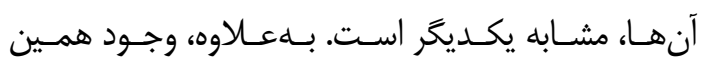

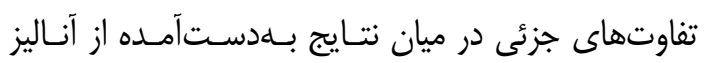

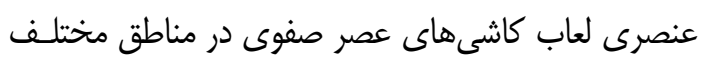

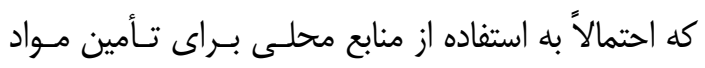

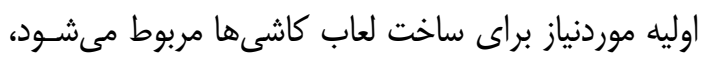

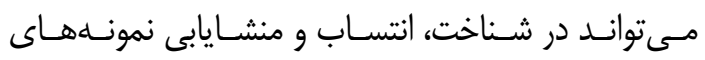

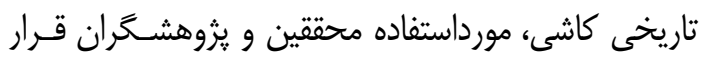

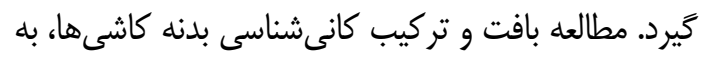

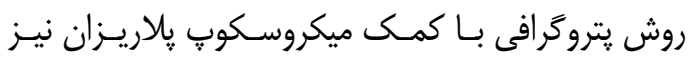

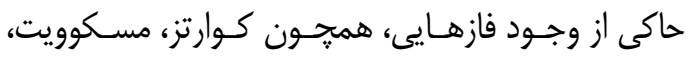

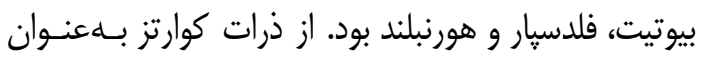

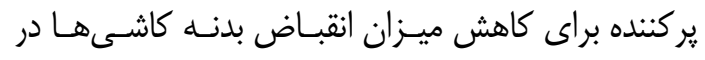




\section{References}

[1] Godard A, Godard Y, Siroux M. Athar-e-Iran. Translated by Sarvghad Moghadam Abolhasan. Mashhad: Astan-e-quds-Razavi; 1992. [in Persian]

$$
\begin{aligned}
& \text { [خـــدار أنــدره. أثـار ايــران. ترجمــهـ ســروقد مقــدم }
\end{aligned}
$$

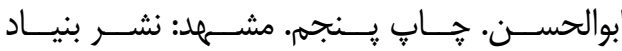

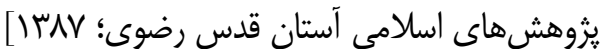

[2] Kiani M Y. Iranian architecture on islamic period. Tehran: SAMT publication; 2001. [in Persian]

$$
\begin{aligned}
& \text { [كيانى يوسف. معمارى ايـران دوره اسـلامى. جــاب }
\end{aligned}
$$

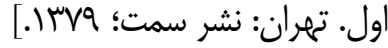

[3] Pope AU, Ackerman P, Besterman T. A survey of Persian art from prehistoric times to the present: Arthur Upham Pope, editor; Phillis Ackerman, assistant editor. vol. 6. Oxford University Press; 1964.

[4] Mollazadeh K. Schools and religious buildings (Takyeh, Hussainia, Khanqah, Qadamgah, School, Musalla). Tehran: Sooreh Mehr publication; 2003. [in Persian]

[ملازاده كاظم. مــدارس و بناهـاى مـذهبى (تكيـه،

حسينيه، خانقاه، قدمگاه، مدرسه، مصلام). جـاب اول.

$$
\text { تקران: سوره مهر؛ [1با.] }
$$

[5] Masoomi M. History of the science of archaeology. Tehran: SAMT Publication; 2005. [in Persian]

[معصومى غلامرضا. تاريخجه علم باسـتانشناسـى.

$$
\text { جاب اول. تهران: نشر سمت؛ سرسا.] }
$$

[6] Diez E. Churasanische Baudenkmäler. vol. 7. Reimer; 1918.

[7] Lamehi-Rachti M, Oliaiy P, Rahighi J, Shokouhi F, Fakhrai M. Application of PIXRF in the analysis of archaeological glazed tiles. Nuclear Instruments and Methods in Physics Research Section B: Beam Interactions with Materials and Atoms 2001;184:430-6. doi:https://doi.org/10.1016/S0168583X(01)00791-1.

[8] Abed Esfahani A, Zahedian K. Surveying the elements changing the colors of the yellow and green enamels of the 7-coloerd (haft-rang) tiles in ImamMosqe ofIsfahan (Safavid Era). Maremat \& Pazhouhesh 2007;2(3):37-42. [in Persian]

$$
\begin{aligned}
& \text { [عابد اصـفهانى عبـاس، زاهـديان كتـايون. بررسـى }
\end{aligned}
$$

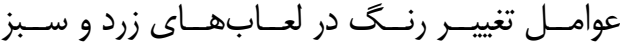

$$
\begin{aligned}
& \text { كاشىهاى هفترنــ مسـجد امـام اصـفهان (دوره }
\end{aligned}
$$

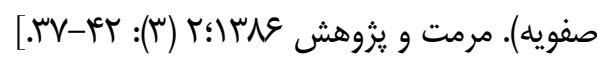

[9] Soltanzadeh S, Vatandoust R, Bahraman A.
Conservation and restoration of the damages made on glade of the 7-colored tiles Imam Ali (PBUH) Holy Shrine. Maremat \& Pazhouhesh 2009;3(6):37-42. [in Persian]

$$
\begin{aligned}
& \text { ]سلطانزاده شـادى، وطـنـدوسـت رسـول، بهرمـان } \\
& \text { عليرضا. طرح حفاظت و مرمت رنختيريـدگى لعـاب } \\
& \text { كاشى هاى هفترنغ حرم حضرت على (ع). مرمست }
\end{aligned}
$$

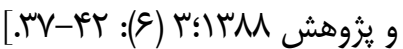

[10] Holakooei P. Technological study of the seventeenth century haft rang tiles in Iran with a comparative view to the cuerda seca tiles in Spain (Doctoral dissertation, Università degli Studi di Ferrara).

[11] Mishmastnehi M, Holakooei P. Technological study of the gilded haft-rang tiles of the Imamzadih Ismail mausoleum in Qazvin, Iran. Heritage Science 2015;3:15. doi:https:// doi.org/10.1186/s40494-015-0044-3.

[12] Kiani M Y. Decorations related with the Iranian architecture of the Islamic period. Tehran: Iranian Cultural Heritage Organization; 2004. [in Persian]

$$
\begin{aligned}
& \text { [كيانى يوسف. تزئينات وابسـته بــه معمـارى ايـران } \\
& \text { دوره اسلامى. جاٍ اول. تهران: نشر سازمان ميـراث } \\
& \text { فرهنگ كشور؛ }
\end{aligned}
$$

[13] Porter V. Islamic tiles. British Museum Press; 1995.

[14] Eppler RA. Corrosion of glazes and enamels. Corros glas ceram ceram supercond noyes pubs 1992.

[15] Gradmann R. Analysis of historical islamic glazes and the development of a substitution material 2016

[16] Abbasiyan MM. Analysis of historical islamic glazes and the development of a substitution. Tehran: Gutenberg publication; 1992. [in Persian]

$$
\begin{aligned}
& \text { ] عباسـيان ميـر محمــد. صــنعت لعـاب سـازى و }
\end{aligned}
$$

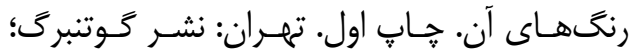

$[.1 \% \mathrm{r} \cdot$

[17] Rahimi A MM. The technology of white wares. 2003. [in Persian]

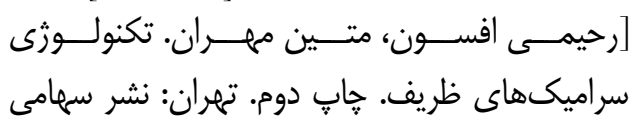

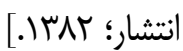

[18] Riederer J. Thin section microscopy applied to the study of archaeological ceramics. Hyperfine Interactions 2004;154:143-58. doi:https:// doi.org/10.1023/B:HYPE.0000032029.24557. b1.

[19] Nourzehi Z, Ajorloo B, B Kasiri M. The Archaeo-mineralogy of the bronze age pottery 
shreds from Kul-tepe of Ajabshir, Eastern lake Urmia Basin, Iran. Journal of Research on Archaeometry 2017;2(2):1-17. [Original in Persian with English Abstract]

[نورزهى زينب، آجرلو بهرام، باقرزاده كثيرى مسعود،

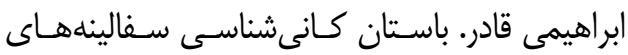

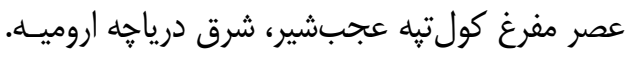

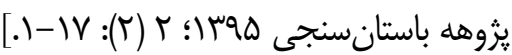

[20] Noghani S, Emami M. Structural pattern of parthian clinky pottery: An Archaeometric Study. Archaeological Studies 2012;3(2):15-34. [Original in Persian with English Abstract]

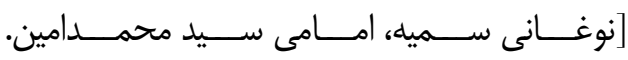

ساختارشناسى سفال جلينكى متعلق به دوران يـارتى

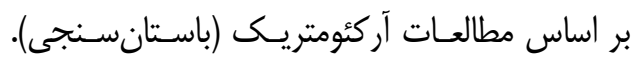

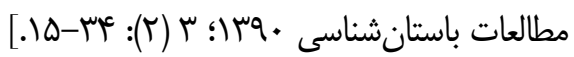

[21] Cultrone G, Rodriguez-Navarro C, Sebastian E, Cazalla O, De La Torre MJ. Carbonate and silicate phase reactions during ceramic firing. European Journal of Mineralogy 2001;13:62134. doi:https://doi.org/10.1127/0935-1221/ 2001/0013-0621.

[22] Rodriguez-Navarro C, Cultrone G, SanchezNavas A, Sebastian E. TEM study of mullite growth after muscovite breakdown. American Mineralogist 2003;88:713-24. doi:https:// doi.org/10.2138/am-2003-5-601. 